\title{
Daytime HONO vertical gradients during SHARP 2009 in Houston, TX
}

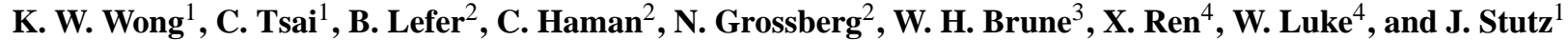 \\ ${ }^{1}$ University of California Los Angeles, Department of Atmospheric and Oceanic Sciences, Los Angeles, CA 90095, USA \\ ${ }^{2}$ Department of Earth and Atmospheric Science, University of Houston, Houston, TX 77204-5007, USA \\ ${ }^{3}$ Department of Meteorology, Pennsylvania State University, University Park, PA 16802, USA \\ ${ }^{4}$ Air Resources Laboratory, National Oceanic and Atmospheric Administration, Silver Spring, MD 20910, USA
}

Correspondence to: J. Stutz (jochen@atmos.ucla.edu)

Received: 12 August 2011 - Published in Atmos. Chem. Phys. Discuss.: 30 August 2011

Revised: 17 November 2011 - Accepted: 2 January 2012 - Published: 16 January 2012

\begin{abstract}
Nitrous Acid (HONO) plays an important role in tropospheric chemistry as a precursor of the hydroxyl radical $(\mathrm{OH})$, the most important oxidizing agent in the atmosphere. Nevertheless, the formation mechanisms of HONO are still not completely understood. Recent field observations found unexpectedly high daytime HONO concentrations in both urban and rural areas, which point to unrecognized, most likely photolytically enhanced HONO sources. Several gas-phase, aerosol, and ground surface chemistry mechanisms have been proposed to explain elevated daytime HONO, but atmospheric evidence to favor one over the others is still weak. New information on whether HONO formation occurs in the gas-phase, on aerosol, or at the ground may be derived from observations of the vertical distribution of $\mathrm{HONO}$ and its precursor nitrogen dioxide, $\mathrm{NO}_{2}$, as well as from its dependence on solar irradiance or actinic flux.
\end{abstract}

Here we present field observations of $\mathrm{HONO}, \mathrm{NO}_{2}$ and other trace gases in three altitude intervals $(30-70 \mathrm{~m}, 70$ $130 \mathrm{~m}$ and $130-300 \mathrm{~m}$ ) using UCLA's long path DOAS instrument, as well as in situ measurements of $\mathrm{OH}, \mathrm{NO}$, photolysis frequencies and solar irradiance, made in Houston, TX, during the Study of Houston Atmospheric Radical Precursor (SHARP) experiment from 20 April to 30 May 2009. The observed HONO mixing ratios were often ten times larger than the expected photostationary state with $\mathrm{OH}$ and NO. Larger HONO mixing ratios observed near the ground than aloft imply, but do not clearly prove, that the daytime source of HONO was located at or near the ground. Using a pseudo steady-state (PSS) approach, we calculated the missing day- time HONO formation rates, $\mathrm{P}_{\text {unknown }}$, on four sunny days. The $\mathrm{NO}_{2}$-normalized $\mathrm{P}_{\text {unknown }}, \mathrm{P}_{\text {norm }}$, showed a clear symmetrical diurnal variation with a maximum around noontime, which was well correlated with actinic flux $\left(\mathrm{NO}_{2}\right.$ photolysis frequency) and solar irradiance. This behavior, which was found on all clear days in Houston, is a strong indication of a photolytic $\mathrm{HONO}$ source. [HONO]/[NO $\left.\mathrm{NO}_{2}\right]$ ratios also showed a clear diurnal profile, with maxima of $2-3 \%$ around noon. PSS calculations show that this behavior cannot be explained by the proposed gas-phase reaction of photoexcited $\mathrm{NO}_{2}\left(\mathrm{NO}_{2}^{*}\right)$ or any other gas-phase or aerosol photolytic process occurring at similar or longer wavelengths than that of HONO photolysis. HONO formation by aerosol nitrate photolysis in the UV also seems to be unlikely.

$\mathrm{P}_{\text {norm }}$ correlated better with solar irradiance (average $R^{2}=0.85 / 0.87$ for visible/UV) than with actinic flux $\left(R^{2}=0.76\right)$ on the four sunny days, clearly pointing to HONO being formed at the ground rather than on the aerosol or in the gas-phase. In addition, the observed $[\mathrm{HONO}] /\left[\mathrm{NO}_{2}\right]$ diurnal variation can be explained if the formation of HONO depends on solar irradiance, but not if it depends on the actinic flux. The vertical mixing ratio profiles, together with the stronger correlation with solar irradiance, support the idea that photolytically enhanced $\mathrm{NO}_{2}$ to $\mathrm{HONO}$ conversion on the ground was the dominant source of $\mathrm{HONO}$ in Houston. 


\section{Introduction}

The rapid photolysis of nocturnal nitrous acid (HONO) (Reaction R1) at sunrise is known to efficiently produce hydroxyl radicals $(\mathrm{OH})$ during a time when other $\mathrm{HO}_{\mathrm{x}}$ sources, such as the photolysis of ozone and formaldehyde, are still weak.

$\mathrm{HONO}+h v \stackrel{\lambda<400 \mathrm{~nm}}{\longrightarrow} \mathrm{OH}+\mathrm{NO}$

The $\mathrm{OH}$ contributed by HONO photolysis in the morning can initiate and accelerate daytime photochemistry. After sunrise, HONO concentrations typically decrease rapidly due to the combined effects of photolysis and enhanced vertical mixing. Until recently, HONO was expected to reach a pseudo steady-state between its gas-phase formation from $\mathrm{NO}$ and $\mathrm{OH}$ (Reaction R2), its photolysis (Reaction R1), and its gas-phase reaction with $\mathrm{OH}$ (Reaction R3) during the rest of the day. Its pseudo steady-state mixing ratio ([HONO $\left.]_{\mathrm{ss}}\right)$ can be calculated based on Eq. (1), where $k_{2}$ and $k_{3}$ are the reaction constants of Reactions $(\mathrm{R} 2)$ and (R3), $J_{\mathrm{HONO}}$ is the photolysis constant of $\mathrm{HONO}$, and $[\mathrm{NO}]$ and $[\mathrm{OH}]$ are the concentrations of $\mathrm{NO}$ and $\mathrm{OH}$. The theoretical steadystate HONO mixing ratios have been calculated to be in the low ppt range (less than $10 \mathrm{ppt}$ ) during the day (Kleffmann, 2007).

$$
\begin{aligned}
& \mathrm{NO}+\mathrm{OH} \longrightarrow \mathrm{HONO} \\
& \mathrm{HONO}+\mathrm{OH} \longrightarrow \mathrm{NO}_{2}+\mathrm{H}_{2} \mathrm{O} \\
& {[\mathrm{HONO}]_{\mathrm{ss}}=\frac{k_{2}[\mathrm{NO}][\mathrm{OH}]}{J_{\mathrm{HONO}}+k_{3}[\mathrm{OH}]}}
\end{aligned}
$$

However, recent field experiments in both urban and rural areas showed that daytime HONO concentrations can reach up to a few hundred ppt (for the remainder of the manuscript we will use ppt as the equivalent of pmol mol${ }^{-1}$ ), substantially higher than the expected $[\mathrm{HONO}]_{\mathrm{ss}}$ (e.g. Kleffmann et al., 2005; Acker et al., 2006a; Zhou et al., 2007). These elevated HONO levels during the day have a significant impact on the $\mathrm{OH}$ budget. In urban and remote areas up to $55 \%$ of the total $\mathrm{OH}$ budget during the day can be attributed to HONO photolysis in the morning and throughout the day (Mao et al., 2010; Elshorbany et al., 2009; Acker et al., 2006b; Kleffmann et al., 2005; Aumont et al., 2003; Alicke et al., 2002).

Despite its importance, the source of HONO is not yet been completely understood. It is generally believed that heterogeneous nitrogen dioxide $\left(\mathrm{NO}_{2}\right)$ conversion on humid surfaces, either through disproportionation or reaction with adsorbed organics, is the most important formation pathway of HONO in the nocturnal boundary layer (NBL) (FinlaysonPitts et al., 2003; Stutz et al., 2004; Wong et al., 2011). Heterogeneous reactions on fresh organic aerosols can play a role in HONO formation during rush hour (Ziemba et al.,
2010; Wong et al., 2011). These formation pathways, together with the inefficient vertical mixing at night, allow HONO to accumulate in the NBL. Up to several ppb of HONO have been observed in the urban NBL (Stutz et al., 2010; Lammel and Cape, 1996; Platt et al., 1980).

As the known nocturnal HONO formation pathways appear to be too slow to explain elevated daytime HONO observations, additional, thus far poorly understood, sources of HONO in the sunlit atmosphere have been implied. Different photolytic formation pathways of HONO have been proposed based on recent laboratory and field experiments $(\mathrm{Li}$ et al., 2008; Stemmler et al., 2006; George et al., 2005; Zhou et al., 2007; Kleffmann, 2007). Generally one can distinguish gas-phase mechanisms and heterogeneous mechanisms on aerosol or at the ground.

Bejan et al. (2006) proposed that the gas-phase photolysis of ortho-nitrophenols could contribute to the formation of daytime HONO in more polluted urban atmospheres. Laboratory experiments showed that the HONO formation rate was linearly dependent on nitrophenol concentrations in the presence of light. A linear dependence of the HONO yield on light intensity and photolysis of $\mathrm{NO}_{2}$ in the spectral region between 300-500 $\mathrm{nm}$ was observed, suggesting that this pathway can occur in the atmosphere. The gas phase reaction of photoexcited $\mathrm{NO}_{2}\left(\mathrm{NO}_{2}^{*}\right)$ with water vapor as a daytime source of HONO has received considerable attention in recent years, following the laboratory measurements by $\mathrm{Li}$ et al. (2008, 2009). While there is considerable disagreement on the rate and branching ratio of the $\mathrm{NO}_{2}^{*}+\mathrm{H}_{2} \mathrm{O}$ reaction (Crowley and Carl, 1997; Carr et al., 2009), a modeling study by Ensberg et al. (2010) has shown that, at the higher reported rate, this reaction could potentially be important. The formation rate of HONO from both mechanisms should be proportional to the actinic flux in the atmosphere. In the case of the photoexcited $\mathrm{NO}_{2}$ pathway the $\mathrm{HONO}$ formation rate should also be linearly dependent on $\mathrm{NO}_{2}$ mixing ratios. In the case of ortho-nitrophenols there is most likely a correlation with $\mathrm{NO}_{2}$ because their primary source is traffic emissions, although the functional dependence is less well defined.

Heterogeneous $\mathrm{NO}_{2}$ to $\mathrm{HONO}$ conversion was proposed to be enhanced by solar irradiance on some types of surfaces. George et al. (2005) found that $\mathrm{NO}_{2}$ conversion to $\mathrm{HONO}$ on films of aromatic compounds, such as phenols and aromatic ketones, was greatly enhanced (by 1-2 orders of magnitude) when irradiated with light of $300-420 \mathrm{~nm}$, compared to the dark reaction. Sosedova et al. (2011) showed that heterogeneous reactions of $\mathrm{NO}_{2}$ on phenols can lead to the formation of particulate-phase nitrophenols, which, upon photolysis, lead to formation of HONO. Stemmler et al. (2006) expanded this mechanism to explain $\mathrm{NO}_{2}$ to $\mathrm{HONO}$ conversion on humic acids and soil surfaces. In detail, they proposed a mechanism where the photolysis of surface adsorbed humic acid in the broad spectral range of 300-700 nm leads to the activation of reductive centers $\left(\mathrm{A}^{\mathrm{red}}\right)$ in the organic film at the 
surface and an oxidant. The reaction of $\mathrm{A}^{\text {red }}$ with $\mathrm{NO}_{2}$ then leads to the formation of gas-phase HONO. Based on their laboratory observation, photoenhanced formation of $\mathrm{HONO}$ ( $\mathrm{P}_{\mathrm{HONO}}$ ) is first order in $\mathrm{NO}_{2}$ at low $\mathrm{NO}_{2}$ mixing ratios, such as those found in a semi-polluted atmosphere. The formation rate was also found to depend linearly on irradiance (Eq. 2).

$\mathrm{P}_{\mathrm{HONO}} \propto$ surface area $\cdot\left[\mathrm{NO}_{2}\right] \cdot$ Irradiance

Another proposed daytime HONO formation mechanism is the photolysis of surface adsorbed nitric acid $\left(\mathrm{HNO}_{3}\right)$. This formation pathway has been suggested to be important, based on field measurements in remote areas (Zhou et al., 2007; He et al., 2006; Beine et al., 2002; Dibb et al., 2002) and laboratory studies on glass sample manifold surfaces (Zhou et al., 2002, 2003). Recently, Zhou et al. (2011) also reported HONO emission flux measurements above a forest canopy in a rural area, which they attribute to the photolysis of $\mathrm{HNO}_{3}$ adsorbed on leaves. HONO formation through surface $\mathrm{HNO}_{3}$ photolysis is proportional to UV solar irradiance and the amount of surface adsorbed $\mathrm{HNO}_{3}$. Zhou et al. (2011) report no clear correlation with $\mathrm{NO}_{\mathrm{x}}$ or $\mathrm{NO}_{2}$, but rather with $\mathrm{NO}_{\mathrm{y}}$.

Both heterogeneous mechanisms described above can potentially also occur on aerosol particles. Stemmler et al. (2007) found that the humic acid pathway on aerosol is most likely not important, as the observed uptake coefficients in the laboratory were too small. However, other unrecognized HONO formation through the aerosol phase cannot be excluded. One would expect that most processes would be linearly dependent on $\mathrm{NO}_{2}$ mixing ratios. This includes the $\mathrm{HNO}_{3}$ photolysis pathway if aerosol nitrate is well correlated with gas-phase $\mathrm{NO}_{2}$. In contrast to the surface HONO formation, the HONO formation rate on aerosol would be proportional to the actinic flux, i.e. total solar irradiance over the aerosol surfaces, rather than solar irradiance.

A new ground source of daytime HONO was recently proposed by $\mathrm{Su}$ et al. (2011). In this study, soil nitrate was shown to be a strong source of daytime HONO. The emission of HONO from soil showed diurnal variations with a maximum at noon, with a magnitude similar to the observed missing HONO source. The emission of HONO does not have a dependence on gas-phase $\mathrm{NO}_{2}$, but rather on the nitrite concentration in the soil, which depends on soil acidity and temperature.

Another HONO source active during the daytime in urban and semi-urban areas is the direct emission from combustion processes (Kurtenbach et al., 2001; Pitts et al., 1984; Kessler and Platt, 1984). This source would be independent of actinic flux or solar irradiance, unless temporal traffic patterns correlate with the temporal behavior of solar irradiance. On the other hand $\mathrm{NO} / \mathrm{NO}_{2}$ and $\mathrm{HONO}$ are co-emitted and a HONO- $\mathrm{NO}_{2}$ correlation can be expected.

Most field studies of daytime HONO have been based on point measurements at one altitude (Acker et al., 2006a,b;
Kleffmann et al., 2005; Zhou et al., 2001, 2002, 2007, 2011; Ren et al., 2010, 2011; Ziemba et al., 2010). In general, these studies found that HONO mixing ratios in urban areas peaked in the morning and decreased throughout the day, or had a minimum at noon (Acker et al., 2006a; Alicke et al., 2002, 2003; Villena et al., 2011; Elshorbany et al., 2009). In remote and semi-rural areas, HONO mixing ratios were found to either peak at noontime (Acker et al., 2006b; Zhou et al., 2001, 2011) or to peak in the morning similar to observations in urban areas (Zhou et al., 2007; Kleffmann et al., 2003).

HONO to $\mathrm{NO}_{2}$ ratios were observed to have some diurnal variation, which tended to peak at midday in urban areas and correlate with the photolysis frequency of $\mathrm{NO}_{2}$ (Acker et al., 2006a; Villena et al., 2011; Elshorbany et al., 2009). The diurnal pattern of $[\mathrm{HONO}] /\left[\mathrm{NO}_{2}\right]$ ratios was explained to be due to a photolytic HONO source, which was expected to be correlated with the actinic flux or the photolysis frequency of $\mathrm{NO}_{2}$. Larger $[\mathrm{HONO}] /\left[\mathrm{NO}_{2}\right]$ ratios were sometimes observed at higher altitudes, suggesting a possible HONO source aloft (Villena et al., 2011).

Thus far, few observational studies have been performed to measure daytime HONO vertical profiles. Kleffmann (2007) measured daytime HONO concentrations at 10, 30, 100 and $190 \mathrm{~m}$ using the Long Path Absorption Photometer (LOPAP) in a semi-rural area in Germany. No strong vertical gradi-

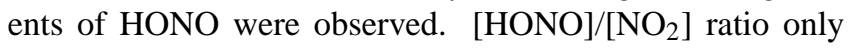
slightly decreased with altitude, suggesting that there could be a potential photolytic HONO source in the gas-phase or on the aerosol. However, vertical gradient measurements at 0.5 and $25 \mathrm{~m}$ in a forest showed no vertical gradients of HONO in the morning and during the day (Sörgel et al., 2011a). Zhang et al. (2009) performed aircraft measurements of HONO vertical profiles in the lowest $2500 \mathrm{~m}$ over a rural area in northern Michigan. Negative HONO vertical gradients were observed during the day, indicating that the ground was a major source of HONO in the lower boundary layer. Significant daytime HONO concentrations measured in the upper boundary layer and in the lower free troposphere suggested that there was an additional source of HONO aloft. No $\mathrm{NO}_{2}$ measurements were presented in this study. However, airborne measurements of HONO in the lowest $1000 \mathrm{~m}$ showed no vertical gradients (Häseler et al., 2009). Villena et al. (2011) took daytime HONO measurements at 6 and $53 \mathrm{~m}$ off a building in an urban area in Chile using LOPAP. Higher concentrations of HONO were also measured near the ground than aloft. The $[\mathrm{HONO}] /\left[\mathrm{NO}_{\mathrm{x}}\right]$ ratio had a diurnal variation which correlated with the photolysis frequency of $\mathrm{NO}_{2}$. Larger $[\mathrm{HONO}] /\left[\mathrm{NO}_{\mathrm{x}}\right]$ ratios were sometimes observed, indicating a possible source of HONO aloft. Daytime HONO measurements were also performed at 0.2 and $5 \mathrm{~m}$ over snow in the Arctic by Zhou et al. (2001). Larger HONO concentrations were observed near the snow and had a solar dependence. 
The vertical distribution of HONO in the daytime boundary layer carries important information on the source and formation of HONO. A strong continuous ground source of HONO would lead to higher concentrations near the ground than aloft. On the other hand, daytime HONO formation on aerosol surfaces should lead to a relatively uniform HONO vertical distribution, assuming the most likely case that the aerosol profile is uniform in the daytime boundary layer. Similarly, gas-phase HONO sources in a well-mixed boundary layer should also be fairly uniform in altitude. Motivated by these arguments, we report here continuous measurements of daytime $\mathrm{HONO}$ and $\mathrm{NO}_{2}$ mixing ratios in three altitude intervals in Houston, TX in Spring 2009. We will use HONO and $\mathrm{NO}_{2}$ profiles together with the correlation of pseudo steady-state $\mathrm{HONO}$ formation rates and $[\mathrm{HONO}] /\left[\mathrm{NO}_{2}\right]$ ratios with solar irradiance/actinic flux to elucidate the source of daytime HONO.

\section{Experimental}

Measurements of daytime $\mathrm{HONO}$ and $\mathrm{NO}_{2}$ vertical concentration profiles were made from 20 April to 30 May during the 2009 Study of Houston Atmospheric Radical Precursors (SHARP), in Houston, TX, using UCLA's long-path Differential Optical Absorption Spectroscopy instrument (LPDOAS). A number of other measurements, in particular of $\mathrm{OH}, \mathrm{NO}$, solar irradiance and actinic flux were also performed. Several other techniques also measured HONO during SHARP. A manuscript comparing these measurements is forthcoming.

\subsection{LP-DOAS}

The LP-DOAS instrument was set up on the roof of the North Moody Tower on the campus of the University of Houston, at an altitude of about $70 \mathrm{~m}$ above the ground. The instrument consists of a $1.5 \mathrm{~m}$ focal length double Newtonian telescope, which is used to send a collimated beam of light from a Xe-arc lamp onto an array of quartz corner-cube retroreflectors. The reflected light is received by the same telescope and fed through a quartz fiber mode-mixer into a $500 \mathrm{~mm}$ Czerny-Turner Spectrometer (Acton Spectra Pro 500) with a photodiode array detector (Hoffmann Messtechnik) (Stutz and Platt, 1997). Retroreflector arrays were mounted on the top of three buildings located in downtown Houston at distances of 4.1, 5.05 and $5.15 \mathrm{~km}$ from the Moody Tower at altitudes of 20, 130 and $300 \mathrm{~m}$ a.g.l., respectively (Fig. 1). The LP-DOAS telescope was aimed consecutively at these retroreflectors to measure the absorptions of $\mathrm{HONO}$ and $\mathrm{NO}_{2}$ between the University of Houston and downtown Houston. This setup was very similar to that described in Wong et al. (2011), with the exception of somewhat different locations of the middle and lower retroreflectors.
The LP-DOAS measured atmospheric absorption spectra between $300-380 \mathrm{~nm}$ with a spectral resolution of $0.5 \mathrm{~nm}$ using the multichannel scanning technique (see details in Alicke et al., 2002). The spectral trace gas retrievals of pathaveraged $\mathrm{HONO}$ and $\mathrm{NO}_{2}$ concentrations were performed using the methods outlined in Stutz and Platt (1996) using literature absorption cross sections (Stutz et al., 2000; Vandaele et al., 2002). Errors of $\mathrm{HONO}$ and $\mathrm{NO}_{2}$ mixing ratios were derived in the fitting procedure and will be reported here as $1 \sigma$ statistical uncertainties. The systematic errors of the reported trace gas mixing ratios are dominated by the uncertainties of the absorption cross-sections of HONO $(5 \%)$ and $\mathrm{NO}_{2}$ (3\%) (Stutz et al., 2000; Vandaele et al., 2002). The systematic error of the DOAS spectrometer is $<3 \%$ (Platt and Stutz, 2008). An example of a spectral retrieval of $\mathrm{NO}_{2}$ and daytime HONO path-integrated mixing ratios, along with the statistical errors of the measurements, is shown in Fig. 2. HONO absorptions during the day were clearly identified.

In order to retrieve the vertical gradients, we assumed horizontal and vertical homogeneity in the height intervals shown in Fig. 1. Therefore, the concentrations of the retrieved pathaveraged mixing ratio of the lower and middle light paths are representative for the lower and middle intervals. The concentration of the upper interval was calculated by subtracting the scaled concentration retrieved from the middle light path from the upper light path (see Fig. 1). Consequently, the reported mixing ratios are horizontally averaged between the Moody Tower and downtown Houston, and vertically averaged over the LP-DOAS height intervals: lower: 20-70 m, middle: $70-130 \mathrm{~m}$ and upper: $130-300 \mathrm{~m}$. The statistical errors from the measurement were propagated in this calculation. The best detection limits, calculated as twice the statistical error of the height averaged mixing ratios, for lower/middle/upper height intervals was $15 / 20 / 30 \mathrm{ppt}$ for HONO and 20/20/30 ppt for $\mathrm{NO}_{2}$. As DOAS mixing ratio errors are determined for every data point and thus vary with atmospheric visibility and instrument performance, we also determined the campaign average detection limit to be $32 / 40 / 52$ ppt for HONO and 40/50/130 ppt for $\mathrm{NO}_{2}$. Detection limits for daytime measurements in 2009 were considerably better than in 2006 (Wong et al., 2011) due to better atmospheric visibility in 2009 and improvements to the LPDOAS instrument.

\subsection{Radiation measurement}

In situ radiation measurements were performed on the roof of Moody Tower by the University of Houston. Incident total and diffuse solar visible irradiance data were taken using the BF3 Sunshine Sensor (Delta-T Devices, Cambridge, UK), which uses an array of photodiodes and a computergenerated shading pattern. The BF3 photodiodes are sensitive to solar radiation between $400-700 \mathrm{~nm}$. The BF3 instrument was calibrated just prior to the SHARP campaign by 


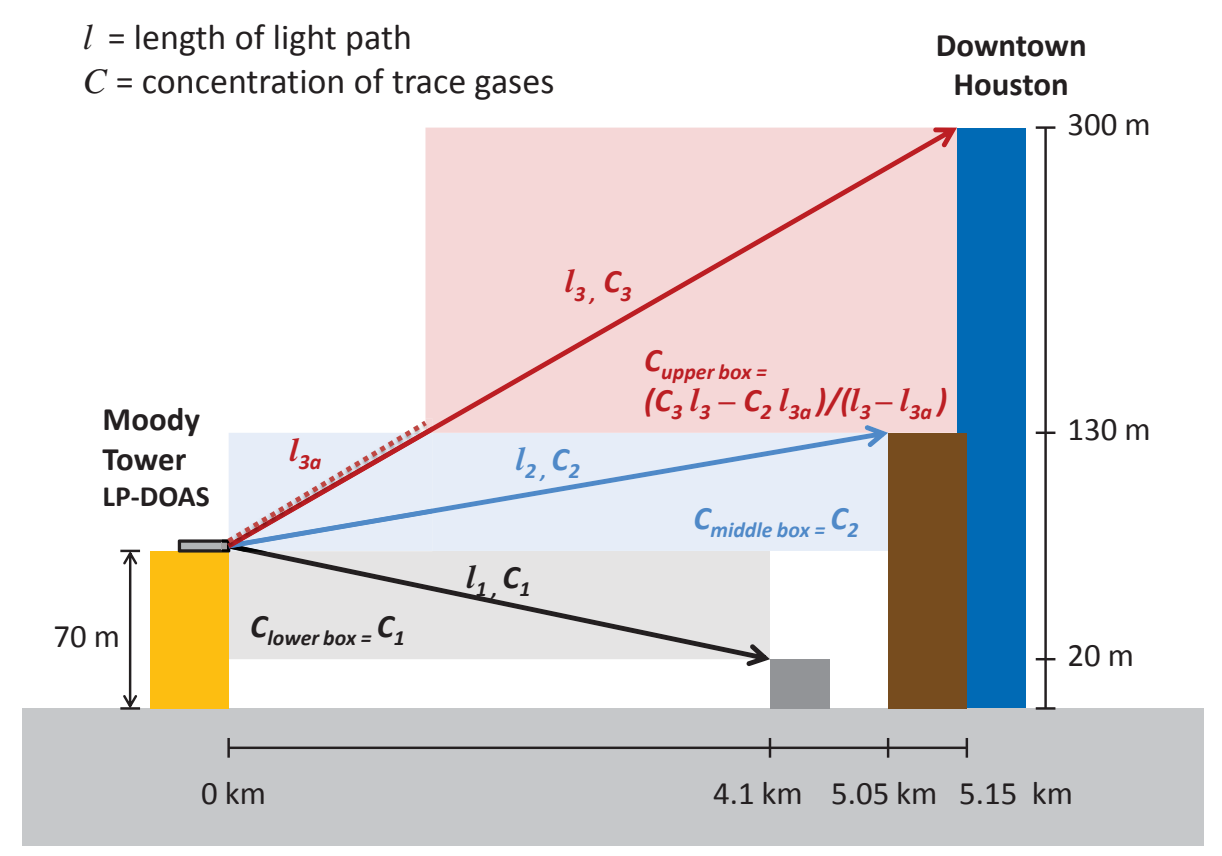

Fig. 1. Schematic figure of the setup of UCLA's LP-DOAS during SHARP 2009, showing the three LP-DOAS light paths and the height intervals for which concentrations were retrieved.
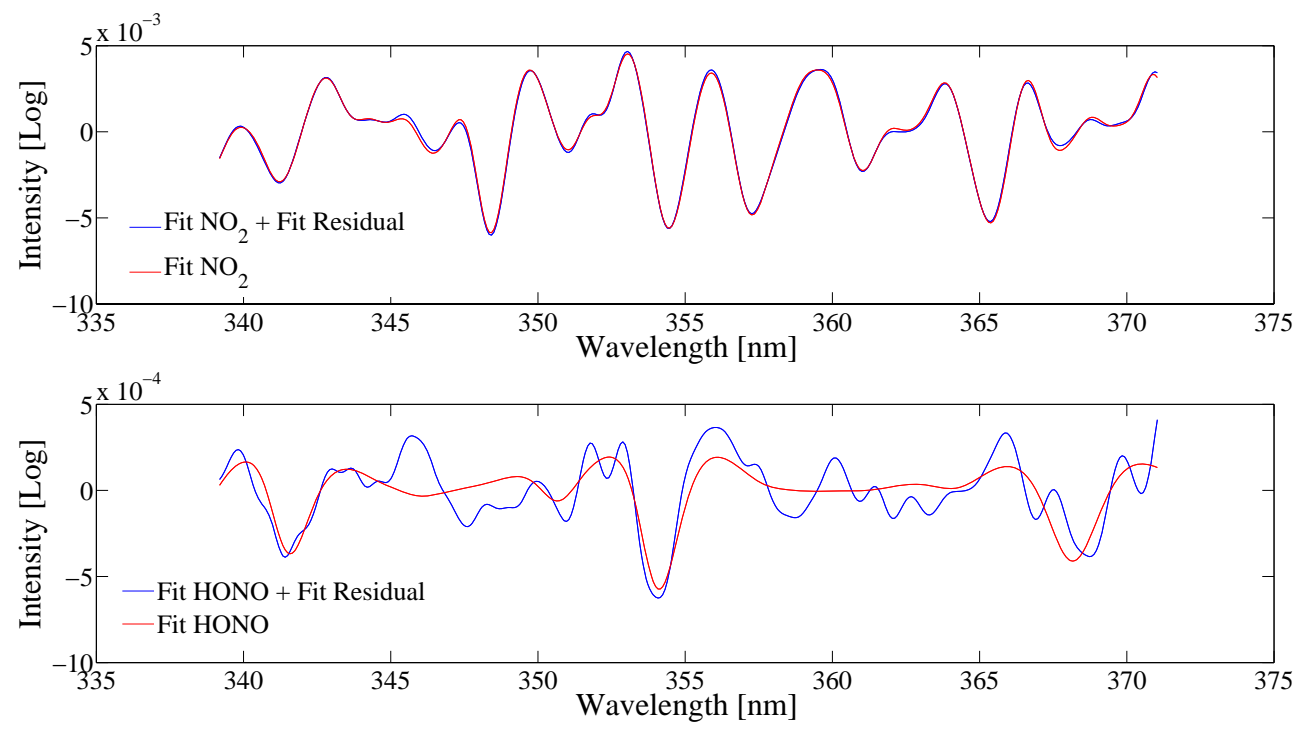

Fig. 2. Example spectra for $\mathrm{NO}_{2}$ (upper) and HONO (lower) analysis. Shown is a comparison of the HONO absorption cross section after adaptation to the instrument function, simulation of the multichannel scanning technique (MCST) procedure, and smoothing, compared to the spectral features after removal of all other trace gas absorptions except $\mathrm{NO}_{2}$ (upper) and $\mathrm{HONO}$ (lower). The retrieved $\mathrm{HONO}$ mixing ratio was $0.139 \pm 0.013 \mathrm{ppb}$ while $\mathrm{NO}_{2}$ was $5.38 \pm 0.031 \mathrm{ppb}$.

the manufacturer which assigns $\pm 12 \%$ overall accuracy for the total irradiance and $\pm 15 \%$ accuracy for the diffuse irradiance under normal climatic conditions. The UV irradiance in the range of $286.5-363 \mathrm{~nm}$ was measured by the Brewer MkIV Spectrophotometer.
Photolysis frequencies of $\mathrm{HONO}$ and $\mathrm{NO}_{2}$ were measured using a scanning actinic flux spectroradiometer (SAFS). The main components of the SAFS instrument are an optical collector, a UV fiber optic bundle, a computer-controlled scanning double monochromator, a low-dark current photomultiplier tube, a four channel signal amplifier, and a data 
acquisition system. The full width at half maximum of the CVI CM112 double monochromator used in this instrument is $1.0 \mathrm{~nm}$ using $2400-\mathrm{g} \mathrm{mm}^{-1}$ gratings and 600 -micron entrance and exit slits. The acquisition time to obtain a $280 \mathrm{~nm}$ to $450 \mathrm{~nm}$ spectrum with $1 \mathrm{~nm}$ steps during SHARP was $30 \mathrm{~s}$. The SAFS monochromator wavelength assignment and instrument function were checked every few days by referencing to a low-pressure mercury lamp spectrum. The absolute spectral sensitivity of each instrument is calibrated in an optical calibration facility using 1000 -watt NIST traceable quartz-tungsten-halogen lamps with uncertainties of 3-4\%. In order to trace any drift in instrument sensitivity, spectral calibrations were also performed every three days in the field, using secondary 250-watt QTH calibration lamps mounted in a field calibration unit. More details regarding the SAFS instrument operation can be found in Lefer et al. (2003) and a thorough uncertainty analysis of the SAFS instrument is discussed by Shetter et al. (2002). Photolysis frequencies were calculated from actinic flux using temperature and pressure dependent molecular absorption cross-sections and photolysis quantum yields provided by Sander et al. (2006).

\subsection{OH measurement}

$\mathrm{OH}$ mixing ratios were measured using the Ground-based Tropospheric Hydrogen Oxides Sensor (GTHOS) (Faloona et al., 2004; Mao et al., 2010). The air sample is pulled through an orifice ( $1.0 \mathrm{~mm}$ dia) into a low-pressure (4-5 hPa) chamber. As the air passes through a pulsed laser beam, $\mathrm{OH}$ is excited by the laser and then detected at wavelengths near $308 \mathrm{~nm}$. Collisional quenching of the excited state is slow enough at the chamber pressure that the weak $\mathrm{OH}$ fluorescence extends beyond the prompt scattering (Rayleigh and wall scattering) and is detected with a time-gated microchannel plate (MCP) detector. GTHOS was calibrated before, during, and after the study using the technique described in Faloona et al. (2004). The absolute calibration uncertainty was estimated at $\pm 32 \%$ (at the $95 \%$ - 2 sigma-confidence level). The $\mathrm{OH}$ detection limit can be defined from twice the standard deviation of the background signal and was 0.2 part per trillion by volume, or pptv, for a 30-min integration period. During the SHARP campaign, the GTHOS detection system was mounted approximately $7 \mathrm{~m}$ above the roof of Moody Tower, on the third level of a scaffolding tower. Ambient air was pulled through the system by a vacuum pump that was located directly beneath the measurement tower. The electronics and calibration equipment were housed in an air-conditioned hut that was directly adjacent to the tower.

\subsection{NO measurement}

A research-grade, three-channel ozone chemiluminescence detector (Luke et al., 2007) was used to provide simultaneous in situ measurements of $\mathrm{NO}, \mathrm{NO}_{\mathrm{x}}\left(\mathrm{NO}_{\mathrm{x}}=\mathrm{NO}+\mathrm{NO}_{2}\right)$, and $\mathrm{NO}_{\mathrm{y}}\left(\mathrm{NO}_{\mathrm{y}}=\mathrm{NO}_{\mathrm{x}}+\mathrm{HONO}+\mathrm{HNO}_{3}+\mathrm{PANs}+\mathrm{HO}_{2} \mathrm{NO}_{2}+\right.$ $\left.2 \cdot \mathrm{N}_{2} \mathrm{O}_{5}+\mathrm{RONO}_{\mathrm{x}}+p-\mathrm{NO}_{3}+\mathrm{NOCl}+\ldots\right)$. The detector has been described in Luke et al. (2007) and the methods used to convert $\mathrm{NO}_{2}$ and $\mathrm{NO}_{\mathrm{y}}$ to $\mathrm{NO}$ in Luke et al. (2010). The response time for NO measurements is approximately $1 \mathrm{~s}$, and the detection limit for a 1 min signal integration, based on a $2 \sigma$ noise envelope about the mean, is 10 ppt. Overall uncertainty in the measured $\mathrm{NO}$ data is approximately \pm $(0.010 \mathrm{ppb}+10 \%$ of reported concentration).

\subsection{Meteorological measurement}

In situ meteorological data, such as temperature, wind speed, wind direction and relative humidity, were measured by the University of Houston on Moody Tower (Lefer et al., 2010). Temperature and relative humidity were measured with a Vaisala HMP45C. Wind speed and wind direction measurements were performed using a R.M. Young Wind Monitor (CS Model 05103). Boundary layer height was determined by an aerosol backscatter ceilometer (Vaisala CL31), using the Vaisala minimum gradient planetary boundary layer height algorithm 3.5.

\section{Observations}

Daytime HONO mixing ratios were observed by the LPDOAS on 37 days of the 41 day long SHARP experiment. In this study, we concentrate on 4 sunny days, which allow a more detailed analysis of the photochemistry of HONO. As the diurnal behavior of HONO is similar on these days we will discuss two days (21 April and 18 May 2009), in more detail in this section. Cloudy days also showed daytime HONO mixing ratios which were larger than the expected photostationary state mixing ratios, but the interpretation approach described below is not applicable.

\subsection{April 2009}

21 April 2009 (Fig. 3) was characterized by westerly flow with wind speed between 4 to $10 \mathrm{~m} \mathrm{~s}^{-1}$ (Fig. 3c). Temperature increased from $290 \mathrm{~K}$ at sunrise to $302 \mathrm{~K}$ in the late afternoon, and relative humidity decreased from $60 \%$ at sunrise to less than $30 \%$ in the afternoon (Fig. 3b). Actinic flux, shown here as $J_{\mathrm{HONO}}$, showed that 21 April was a sunny day without clouds (Fig. 3a). Boundary layer heights, as determined by the ceilometer, grew from $\sim 100 \mathrm{~m}$ at sunrise to $\sim 1500 \mathrm{~m}$ in the afternoon (Fig. 3a).

$\mathrm{NO}_{2}$ mixing ratios showed a distinct diurnal behavior (Fig. 3e). Mixing ratios in the lower and middle height interval were elevated in the early morning due to rush hour emissions and a shallow boundary layer. During the same time period $\mathrm{NO}_{2}$ mixing ratios aloft were only $\sim 1 \mathrm{ppb}$. As a consequence of vertical mixing, the $\mathrm{NO}_{2}$ mixing ratios near the ground decreased, while those aloft increased between 06:00 CST and 09:00 CS, as the boundary layer started to grow. This early morning behavior is in agreement with our 


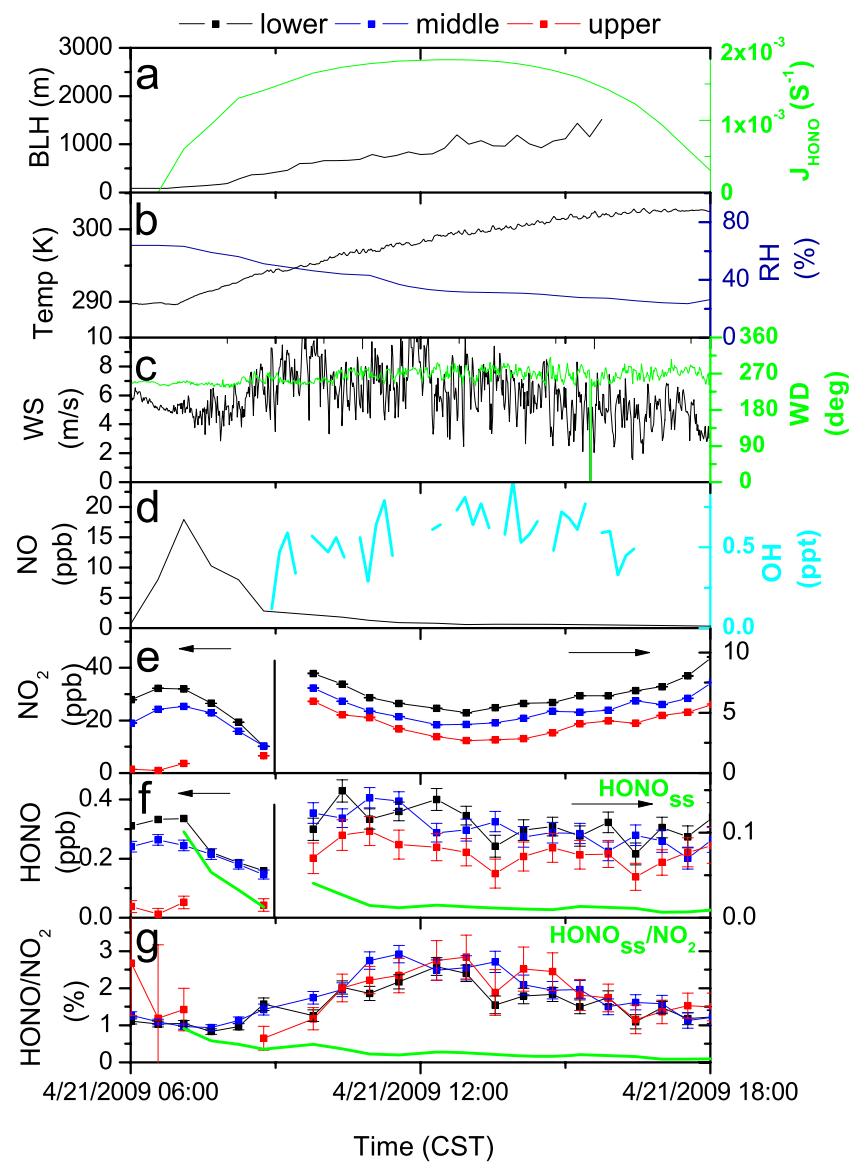

Fig. 3. Timeseries of meteorological data, $J_{\mathrm{HONO}}, \mathrm{NO}, \mathrm{OH}$, $\mathrm{HONO}, \mathrm{NO}_{2}$ and $\mathrm{HONO}$ to $\mathrm{NO}_{2}$ ratio on 21 April 2009. OH data were not available on this day. $\mathrm{OH}$ data shown here are the average of sunny days during SHARP. HONO and $\mathrm{NO}_{2}$ data after 09:00 CST are displayed with different scales on the right y-axis. Error bars of one standard deviation are shown for $\mathrm{NO}_{2}, \mathrm{HONO}$ and $\mathrm{HONO} / \mathrm{NO}_{2}$.

understanding of the morning transition period when mixing and the onset of photolysis leads to a change in the mixing ratios and the vertical distribution of $\mathrm{NO}_{2}$. Interestingly, vertical $\mathrm{NO}_{2}$ mixing ratio gradients did not disappear after the morning transition and remained pronounced throughout the rest of the day. $\mathrm{NO}_{2}$ mixing ratios near the ground decreased from $\sim 10 \mathrm{ppb}$ at 09:00 CST to a minimum of $\sim 7 \mathrm{ppb}$ around noon and then increased again to $\sim 10 \mathrm{ppb}$ around 18:00 CST. This variation can be partially explained by the shift towards $\mathrm{NO}$ in the $\mathrm{NO}-\mathrm{NO}_{2}$ photostationary state at higher $\mathrm{NO}_{2}$ photolysis frequencies. The upper height interval showed mixing ratios of about one-third of those in the lower height interval at 10:00 CST. Around noontime, the $\mathrm{NO}_{2}$ mixing ratio in the upper height interval was only half of that in the lower height interval. The mixing ratios in the middle height interval generally fell between those in the upper and lower intervals. Larger daytime $\mathrm{NO}_{2}$ mixing ratios were observed near the ground than aloft, possibly indicating a strong source of $\mathrm{NO}_{\mathrm{x}}$ from traffic and vertical mixing that was not fast enough to even out its vertical distribution.

Early morning HONO mixing ratios generally followed those of $\mathrm{NO}_{2}$, showing distinct vertical gradients, with larger mixing ratios near the ground than aloft, and decreased from $\sim 0.3 \mathrm{ppb}$ at sunrise to $\sim 0.15 \mathrm{ppb}$ at 09:00 CST (Fig. 3f). Throughout the rest of the day, HONO mixing ratios in all three height intervals remained between 0.05 to $0.15 \mathrm{ppb}$. Generally, HONO mixing ratios decreased slightly throughout the day, in contrast to $\mathrm{NO}_{2}$, which increased after noon. Measurements in urban areas typically show similar diurnal variations in HONO mixing ratios. In contrast to our observations, some measurements in rural environments showed a peak in HONO mixing ratios at solar noon (Acker et al., 2006b; Zhou et al., 2001). Assuming pseudo steady-state among Reactions (R1-R3), we calculated the HONO steadystate mixing ratio (Eq. 1) using in situ data and LP-DOAS HONO observations at the lowest light path. Because $\mathrm{OH}$ data were not available in the morning on 21 April and in the afternoon on 18 May, average $\mathrm{OH}$ data in the morning and afternoon on sunny days during SHARP were used in the calculation. Calculated steady-state HONO mixing ratios were about $0.02 \mathrm{ppb}$ in the late morning and decreased to $0.01 \mathrm{ppb}$ in the afternoon. Observed elevated daytime HONO concentrations indicated a strong unknown source of HONO during the day. HONO mixing ratios also showed statistically significant vertical gradients throughout the day, with smaller mixing ratios in the upper height interval than in the lower and middle intervals. While this may imply a HONO source near the ground, the simultaneous $\mathrm{NO}_{2}$ gradient makes this interpretation more complex, as will be discussed further in Sect. 4.

To further investigate the possible conversion of $\mathrm{NO}_{2}$ to $\mathrm{HONO}$, we calculated the $\mathrm{HONO}$ to $\mathrm{NO}_{2}$ ratio in all height intervals (Fig. $3 \mathrm{~g}$ ). This ratio showed a clear diurnal variation, with values of $\sim 1 \%$ in the early morning, that gradually increased to almost $3 \%$ around noon and then decreased back to $1 \%$ by the late afternoon. The steady-state HONO to $\mathrm{NO}_{2}$ ratio expected based on Eq. (1) was $\sim 1 \%$ at 07:00 CST, similar to the observed HONO to $\mathrm{NO}_{2}$ ratio. However, it decreased to $0.3 \%$ or below during the day, and did not show the observed diurnal variation. The observed ratio was up to ten times larger than the expected steady-state $\mathrm{HONO}$ to $\mathrm{NO}_{2}$ ratio, further showing the existence of an unknown HONO source. The $[\mathrm{HONO}] /\left[\mathrm{NO}_{2}\right]$ ratio did not show pronounced vertical profiles throughout the day.

\subsection{May 2009}

18 May (Fig. 4) was another sunny day, similar to 21 April. However, it was characterized by northerly and northeasterly flow, with wind speeds from 4 to $8 \mathrm{~m} \mathrm{~s}^{-1}$ (Fig. 4c) and temperatures from 288 to $297 \mathrm{~K}$ (Fig. 4b). Boundary layer heights grew from $\sim 100 \mathrm{~m}$ at sunrise to $\sim 2800 \mathrm{~m}$ in the 


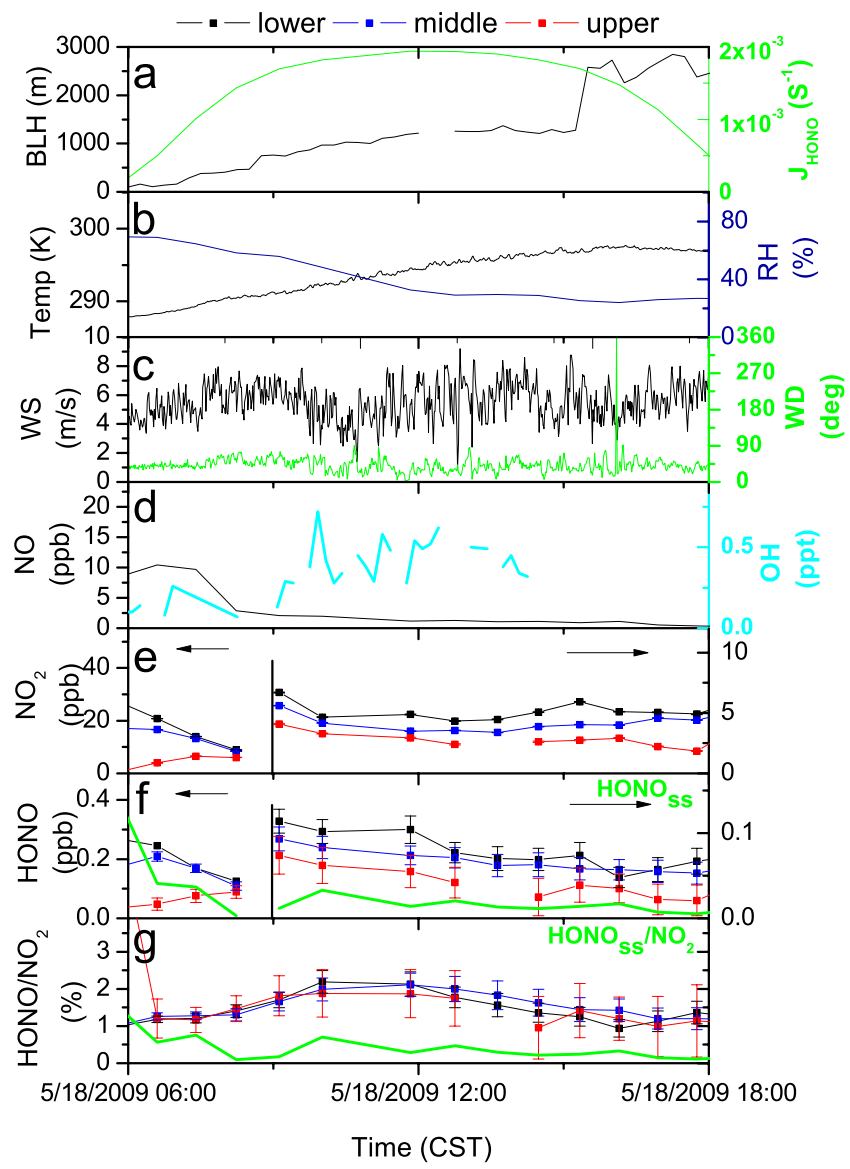

Fig. 4. Timeseries of meteorological data, $J_{\mathrm{HONO}}, \mathrm{NO}, \mathrm{OH}$, $\mathrm{HONO}, \mathrm{NO}_{2}$ and $\mathrm{HONO}$ to $\mathrm{NO}_{2}$ ratio on 18 May 2009. HONO and $\mathrm{NO}_{2}$ data after 09:00 CST are displayed with different scales on the right $\mathrm{y}$-axis. Error bars of one standard deviation are shown for $\mathrm{NO}_{2}, \mathrm{HONO}$ and $\mathrm{HONO} / \mathrm{NO}_{2}$.

afternoon (Fig. 4a). This day had similar relative humidities as 21 April, which varied from $70 \%$ at sunrise to only $25 \%$ in the afternoon (Fig. 4b).

Similar to 21 April, distinct $\mathrm{NO}_{2}$ and $\mathrm{HONO}$ vertical gradients were observed throughout the day, with larger concentrations near the ground than aloft. $\mathrm{NO}_{2}$ in the lower height interval was $27 \mathrm{ppb}$ at sunrise and decreased to $5 \mathrm{ppb}$ at 10:00 CST, remaining at $5 \mathrm{ppb}$ for the rest of the day (Fig. 4e). $\mathrm{NO}_{2}$ mixing ratios in the upper height interval were $1 \mathrm{ppb}$ at sunrise. When the boundary layer started to mix and the $\mathrm{NO}_{2}$ mixing ratios at the middle and lower height intervals decreased, $\mathrm{NO}_{2}$ mixing ratios in the upper height interval increased to $6.5 \mathrm{ppb}$ at 07:30 CST and leveled off afterwards, remaining below 3 ppb throughout the day. $\mathrm{NO}_{2}$ mixing ratios in the upper height interval were about $50 \%$ lower than those in the lower height interval.

HONO mixing ratios developed significant gradients in the morning similar to those on 21 April (Fig. 4f). HONO in the lower height interval was $0.25 \mathrm{ppb}$ at sunrise and decreased to $0.11 \mathrm{ppb}$ at 09:00 CST. HONO in the lower height interval stayed at around $0.1 \mathrm{ppb}$ throughout the day, with a minimum of $0.04 \mathrm{ppb}$ at 16:00 CST. Again, HONO mixing ratios showed a steady decrease throughout the day. The calculated steady-state HONO mixing ratio (Eq. 1) was about $0.015 \mathrm{ppb}$ during the day and was often much smaller than the observed HONO in the lower height interval. Obvious vertical gradients were observed almost throughout the day. HONO in the upper height interval varied between 0.02-0.09 ppb and was often about half of that in the lower height interval.

The HONO to $\mathrm{NO}_{2}$ ratio on this day also showed some diurnal variation, but not as strong as on 21 April (Fig. 4g). At sunrise, $[\mathrm{HONO}] /\left[\mathrm{NO}_{2}\right]$ ratio was $1 \%$. It increased to maximum of $2 \%$ in late morning and around noon time, and decreased gradually in the afternoon. No significant vertical gradients of $[\mathrm{HONO}] /\left[\mathrm{NO}_{2}\right]$ were observed. The theoretical steady-state $[\mathrm{HONO}] /\left[\mathrm{NO}_{2}\right]$ ratio was below $1 \%$ and did not show the diurnal variation of the observed $[\mathrm{HONO}] /\left[\mathrm{NO}_{2}\right]$ ratio.

\section{Discussion}

Daytime HONO mixing ratios on both 21 April and 18 May, as well as most days during the SHARP experiment that are not discussed in detail, were significantly greater than the theoretical steady-state HONO mixing ratios, suggesting an unknown daytime source of HONO existed. In order to quantify the unknown HONO daytime source, we apply a pseudo steady-state (PSS) approach. The use of a PSS approach is justified by the measured photolysis frequencies of HONO, which showed that HONO had a short lifetime of about half an hour in the early morning and less than $10 \mathrm{~min}$ at noon in Houston. We thus assume that during clear and sunny days HONO reaches a pseudo steady-state between the unknown source $\left(\mathrm{P}_{\text {unknown }}\right)$, its direct emission $(E)$, and Reactions (R1-R3). The rate of HONO formation $\left(\frac{d[\mathrm{HONO}]}{d t}\right)$ can thus be expressed by Eq. (3), and $\mathrm{P}_{\text {unknown }}$ can be calculated as shown in Eq. (4).

$$
\begin{aligned}
& \frac{d[\mathrm{HONO}]}{d t}=P_{\mathrm{unknown}}+k_{2}[\mathrm{NO}][\mathrm{OH}]-J_{\mathrm{HONO}}[\mathrm{HONO}] \\
& -k_{3}[\mathrm{HONO}][\mathrm{OH}]+E=0
\end{aligned}
$$

$$
\begin{gathered}
P_{\text {unknown }}=J_{\mathrm{HONO}}[\mathrm{HONO}]+k_{3}[\mathrm{HONO}][\mathrm{OH}] \\
-k_{2}[\mathrm{NO}][\mathrm{OH}]-E
\end{gathered}
$$

\subsection{Quantification of daytime HONO sources}

The HONO formation rate due to Reaction (R2) and the HONO removal rate by Reactions (R1) and (R3) were calculated from the measurements of $\mathrm{HONO}, \mathrm{OH}, \mathrm{NO}$, and

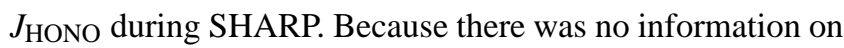
the HONO emission rate, the direct emission rate of HONO 


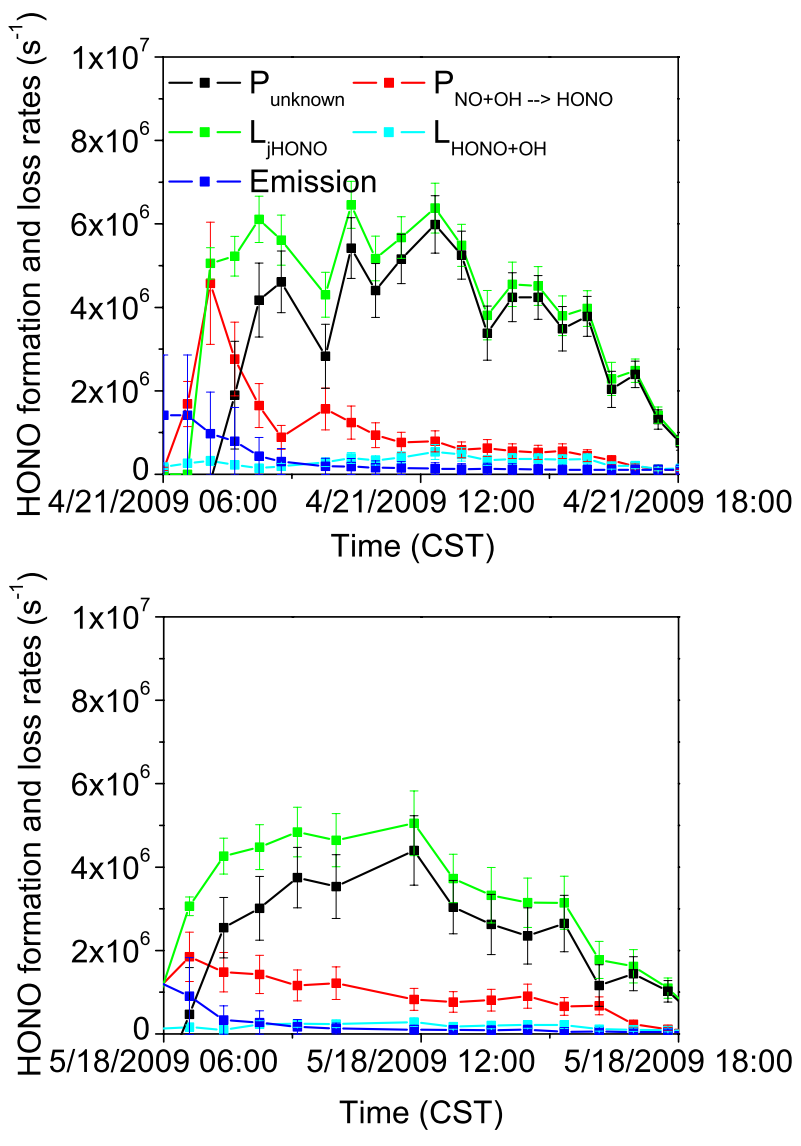

Fig. 5. Timeseries of HONO formation and removal rates in the lower height interval on 21 April 2009 (upper) and 18 May 2009 (lower). Please note that errors were propagated from the statistical uncertainties of the observations.

was estimated using the $\mathrm{NO}_{\mathrm{x}}$ emission rate derived from model studies based on observations taken in the same location in 2006 (Wong et al., 2011). To calculate the contribution of direct emissions, a $\mathrm{HONO} / \mathrm{NO}_{\mathrm{x}}$ emission ratio of $0.35 \%$, which is in the range of that from tunnel measurements (Kurtenbach et al., 2001; Kirchstetter et al., 1996), and the observed boundary layer heights measured by our ceilometer (Figs. 3 and 4) were used.

The formation and loss rates of HONO by Reactions (R1R3), emission, and $\mathrm{P}_{\text {unknown }}$ for 21 April 2009 and 18 May 2009 in the lower height interval are shown in Fig. 5. Photolysis was the dominant removal pathway of HONO in the boundary layer during the day. The loss was highest from around 09:00 CST to 12:00 CST. As the photolytic rate is the product of the HONO mixing ratio, which decreased slowly throughout the day (Figs. 3 and 4), and the photolysis frequency of HONO, which was smooth and symmetric on both days (Figs. 3 and 4), the loss rate was not symmetric around noon. Small fluctuations in the HONO photolytic loss rate throughout the day, as seen on 21 April, were caused by small variations in the HONO mixing ratios. The loss rates of HONO through Reaction (R3) were relatively constant throughout both days and were insignificant compared to the loss rate of $\mathrm{HONO}$ by photolysis.

The formation rate of HONO through Reaction (R2) was important in the early morning, on both days. On 21 April, it was the dominant chemical formation pathway of HONO before 08:00 CST. However, it decreased afterwards on both days. Direct HONO emissions were comparable to the HONO formation through Reaction (R2) in the first couple of hours after sunrise. However, due to the rapid growth of boundary layer height after sunrise, HONO direct emissions were insignificant throughout the rest of the day. It should be noted that our direct emission calculations were based on an $[\mathrm{HONO}] /\left[\mathrm{NO}_{\mathrm{x}}\right]$ emission ratio, which is not well known. However, even at the highest reported $[\mathrm{HONO}] /\left[\mathrm{NO}_{\mathrm{x}}\right]$ emission ratio of $0.8 \%$ the contribution of direct HONO emissions to the overall HONO budget is insignificant.

The results in Fig. 5 show that $\mathrm{P}_{\text {unknown }}$ dominated on both days. It reached a maximum of $6 \times 10^{6} \mathrm{~cm}^{-3} \mathrm{~s}^{-1}$ and $4 \times 10^{6} \mathrm{~cm}^{-3} \mathrm{~s}^{-1}$ at noon on 21 April and 18 May, respectively. While the diurnal pattern of $\mathrm{P}_{\text {unknown }}$ shows an increase towards noon, the formation rate seems to be higher before noon than after noon, in particular on 18 May 2009. This asymmetric pattern on sunny days with a symmetry of the actinic flux around noon shows that $\mathrm{P}_{\text {unknown }}$ does not purely depend on solar irradiance. As discussed in Sect. 1, laboratory studies have shown that $\mathrm{NO}_{2}$ conversion into HONO on certain surfaces can be enhanced by solar irradiance (George et al., 2005; Stemmler et al., 2006, 2007). Following these proposed daytime HONO formation mechanisms, $\mathrm{P}_{\text {unknown }}$ should depend on $\mathrm{NO}_{2}$ mixing ratios. In order to remove this possible $\mathrm{NO}_{2}$ dependence, $\mathrm{P}_{\text {unknown }}$, as calculated in Eq. (4) and shown in Fig. 5, was thus divided by the observed $\mathrm{NO}_{2}$ concentrations. The approach of normalizing the unknown $\mathrm{HONO}$ formation rate with $\mathrm{NO}_{2}$ mixing ratio was also used by a recent study in a semi-rural environment (Sörgel et al., 2011b). This $\mathrm{NO}_{2}$-normalized HONO formation rate, $\mathrm{P}_{\text {norm }}$, displayed in Fig. 6 for the lower and middle height interval, clearly showed a symmetric diurnal variation with a maximum at noon on both days. $\mathrm{P}_{\text {norm }}$ thus follows solar irradiance and actinic flux. While not shown here, similar results were found on all other clear and sunny days investigated in this study (see Sect. 4.2.2). We will discuss the apparent dependence of $\mathrm{HONO}$ formation on $\mathrm{NO}_{2}$ in Sect. 4.2, where different formation pathways will be discussed.

Previous field studies observed a wide range of unknown daytime HONO formation rates from $1 \times 10^{6} \mathrm{~cm}^{-3} \mathrm{~s}^{-1}$ to $3.5 \times 10^{7} \mathrm{~cm}^{-3} \mathrm{~s}^{-1}$ in both rural and urban areas (Acker et al., 2006b; Zhang et al., 2009; Elshorbany et al., 2009; Kleffmann et al., 2005; Zhou et al., 2002; Su et al., 2008; Sörgel et al., 2011b; Ren et al., 2010). Punknown determined in our study is similar to the HONO formation rates reported in semi rural forests (up to $3.5 \times 10^{6} \mathrm{~cm}^{-3} \mathrm{~s}^{-1}$ ) (Kleffmann et al., 2005) and rural mountains (up to $4 \times 10^{6} \mathrm{~cm}^{-3} \mathrm{~s}^{-1}$ ) 

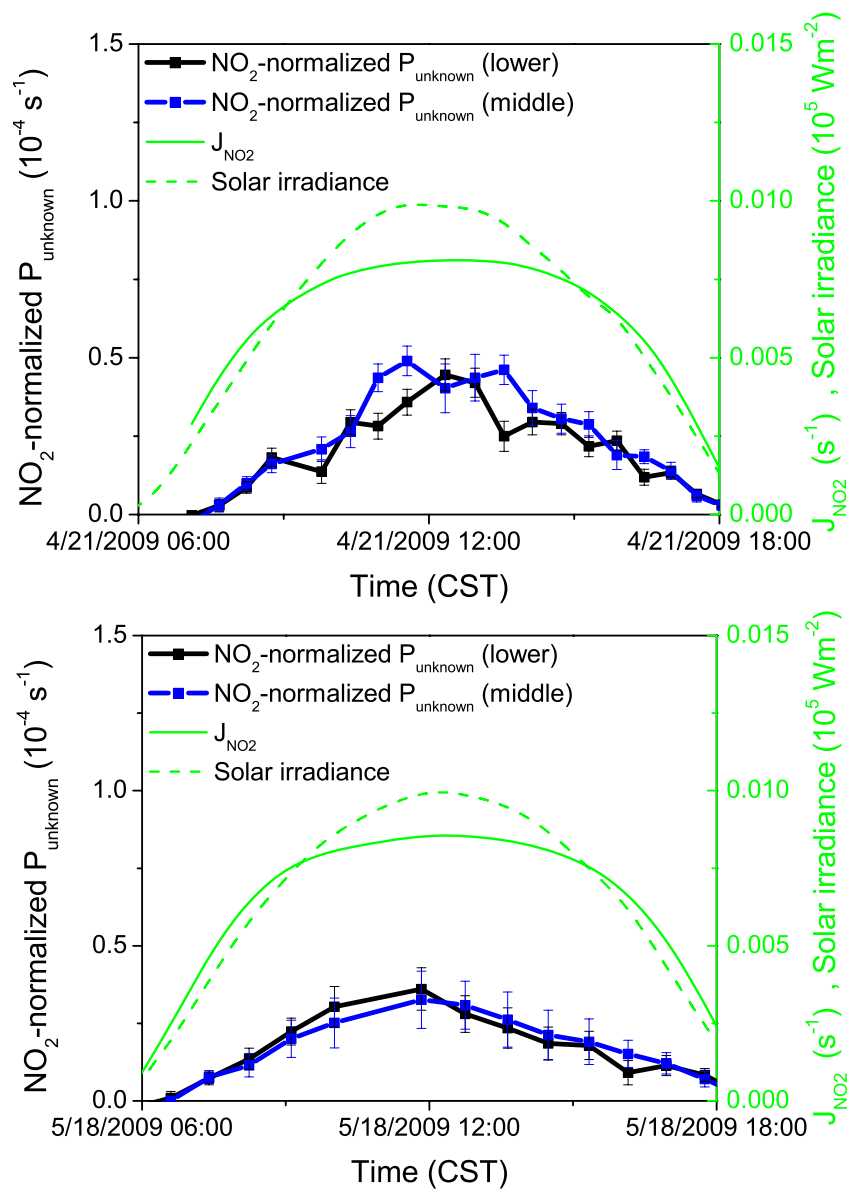

Fig. 6. Timeseries of $\mathrm{NO}_{2}$ normalized $\mathrm{P}_{\text {unknown }}$ in the lower and middle height intervals on 21 April 2009 (upper) and 18 May 2009 (lower). Photolysis frequency of $\mathrm{NO}_{2}$ and solar irradiance are shown as well for comparison.

(Acker et al., 2006b), but smaller than reports from a polluted rural site (Su et al., 2008) and an urban area (Elshorbany et al., 2009).

\subsection{Possible daytime HONO formation pathways}

The observations of diurnal variations of $\mathrm{P}_{\text {unknown }}$ and $\mathrm{P}_{\text {norm }}$, together with the HONO vertical gradients, allow a number of different interpretations of the possible HONO source which we will investigate in the following section:

- HONO was formed by a photolytic gas-phase source that either involves $\mathrm{NO}_{2}$ or that was based on a precursor that showed a similar vertical and temporal profile as $\mathrm{NO}_{2}$, assuming that the actinic flux did not significantly change with altitude.

- HONO was formed by photolytically enhanced conversion of $\mathrm{NO}_{2}$ on the aerosol. If the aerosol profile was fairly uniform in the lowest $300 \mathrm{~m}$ of the atmosphere, and one assumed that actinic flux did not

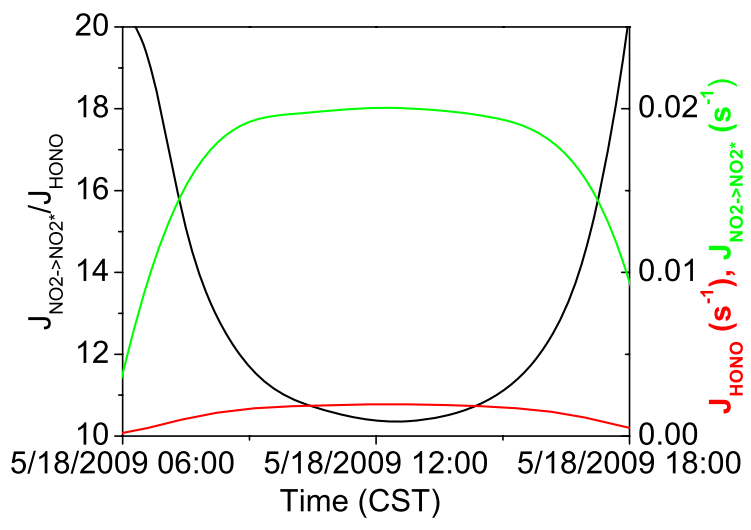

Fig. 7. Measured diurnal variation of the photolysis frequency of $\mathrm{HONO}$, the photolysis frequency of $\mathrm{NO}_{2}$ to photoexcited $\mathrm{NO}_{2}$, and their ratio on a clear and sunny day in Houston.

change, $\mathrm{HONO}$ would reach a steady-state with $\mathrm{NO}_{2}$ at all altitudes, i.e. $[\mathrm{HONO}] /\left[\mathrm{NO}_{2}\right]$ would not show a gradient.

- HONO was formed on the ground by a photolytically enhanced conversion of $\mathrm{NO}_{2}$, and then transported upwards. Vertical gradients of HONO were due to HONO photolysis and/or mixing/dilution. In the turbulent daytime boundary layer, assuming the lifetime of HONO due to photolysis is $12 \mathrm{~min}$ and a vertical transport timescale of about $5 \mathrm{~min}$, photolysis is expected to cause about $30 \%$ decrease in the upper height interval.

\subsubsection{Gas-phase formation}

Although HONO vertical gradients showed larger mixing ratios near the ground than aloft, the existence of similar $\mathrm{NO}_{2}$ vertical gradients makes the interpretation of $\mathrm{P}_{\text {unknown }}$ challenging. One possible explanation of $\mathrm{P}_{\text {unknown }}$ is a gas-phase source which involved $\mathrm{NO}_{2}$ or a trace gas that has a very similar diurnal variation and vertical profile to $\mathrm{NO}_{2}$. This argument assumes that the actinic flux does not change significantly with height, which in the lowest $300 \mathrm{~m}$ of the atmosphere observed by our instrument is normally fulfilled.

One proposed gas-phase HONO formation pathway is the reaction of photoexcited $\mathrm{NO}_{2}$, which is formed at wavelengths between 420 and $650 \mathrm{~nm}$, with water vapor ( $\mathrm{Li}$ et al., 2008). Assuming that this gas-phase formation is the source of daytime HONO, and Reactions (R2) and (R3) are slow, the rate of change of $\mathrm{HONO}$ with time can be written as:

$\frac{d[\mathrm{HONO}]}{d t}=J_{\mathrm{NO}_{2} \rightarrow \mathrm{NO}_{2} *}\left[\mathrm{NO}_{2}\right]$ Yield $_{\mathrm{HONO}}+J_{\mathrm{HONO}}[\mathrm{HONO}]$

$\frac{[\mathrm{HONO}]}{\left[\mathrm{NO}_{2}\right]} \propto \frac{J_{\mathrm{NO}_{2} \rightarrow \mathrm{NO}_{2}} *}{J_{\mathrm{HONO}}}$

Again, using a pseudo steady-state approach, the expected HONO to $\mathrm{NO}_{2}$ ratio should be proportional to the ratio 
of the photolysis frequencies of $\mathrm{NO}_{2}$ and $\mathrm{HONO}$, assuming a constant yield of HONO. The photolysis frequency of $\mathrm{NO}_{2} \rightarrow \mathrm{NO}_{2}^{*}$ was calculated based on our direct observations of actinic flux, the $\mathrm{NO}_{2}$ absorption cross section, and a quantum yield of 1 between 420 and $650 \mathrm{~nm}$. The observed $J_{\mathrm{NO}_{2} \rightarrow \mathrm{NO}_{2} *} / J_{\mathrm{HONO}}$ ratio has a diurnal variation with a slight minimum at noon (Fig. 7) due to the different wavelength ranges of absorption of $\mathrm{HONO}$ and $\mathrm{NO}_{2} \rightarrow \mathrm{NO}_{2}^{*}$. The diurnal variation of the $J_{\mathrm{NO}_{2} \rightarrow \mathrm{NO}_{2} *} / J_{\mathrm{HONO}}$ ratio is thus inverse to the observed diurnal variation of the $[\mathrm{HONO}] /\left[\mathrm{NO}_{2}\right] \mathrm{ra}-$ tio (Fig. $3 \mathrm{~g}$ and $4 \mathrm{~g}$ ), which shows a clear maximum at noon. Therefore, gas-phase HONO formation through the reaction of photoexcited $\mathrm{NO}_{2}$ with water vapor was not the dominant source of daytime HONO. Please note that the choice of the $\mathrm{NO}_{2} \rightarrow \mathrm{NO}_{2}^{*}$ quantum yield has no impact on our argument as we are only analyzing the diurnal behavior and not the absolute formation rate. A recent laboratory study by Amedro et al. (2011) also found that this reaction is not important for daytime HONO formation.

Another proposed gas-phase HONO formation pathway is the photolysis of nitrophenols in the 300-400 nm wavelength range (Bejan et al., 2006). To explain our observations, nitrophenols would have to show a diurnal variation similar to $\mathrm{NO}_{2}$ as well as the same vertical concentration gradients as HONO. It should be noted that the diurnal nitrophenol variation would not just have to be similar to $\mathrm{NO}_{2}$ but precisely related to it on a day by day basis to explain the fairly regular $[\mathrm{HONO}] /\left[\mathrm{NO}_{2}\right]$ behavior. As traffic emissions are believed to be the major source of nitrophenols in the atmosphere (Harrison et al., 2005), one can expect a certain correlation between $\mathrm{NO}_{\mathrm{x}}$ and nitrophenol levels. However, the $\mathrm{NO}-\mathrm{NO}_{2}$ photostationary state that also regulates the $\mathrm{NO}_{2}$ concentrations would weaken this correlation. In addition, nitrophenols have a long lifetime of $\sim 1$ day and should thus have a relatively uniform vertical distribution in the boundary layer. It would thus be fortuitous if nitrophenols would show the same vertical profile as HONO on all days we investigated in Houston. We thus believe that the photolysis of gas-phase nitrophenols is most likely not the main source of the observed daytime HONO.

\subsubsection{Heterogeneous formation on aerosol or ground}

Another possible source of daytime HONO is its formation on aerosol or at the ground. Four different arguments will be discussed in this section to investigate the role of these two types of surfaces in Houston.

The first argument is based on the analysis of the diurnal variation of $\mathrm{P}_{\text {norm. }}$. If $\mathrm{NO}_{2}$ to $\mathrm{HONO}$ conversion occurs on the aerosol, $\mathrm{P}_{\text {norm }}$ should be proportional to the actinic flux and the aerosol surface area concentration. The symmetric diurnal variation of $\mathrm{P}_{\text {norm }}$ (Fig. 6) implies that the aerosol surface area concentration had to be fairly constant throughout the day if HONO formation occurred on the aerosol. However, the aerosol surface area concentrations (not shown) as
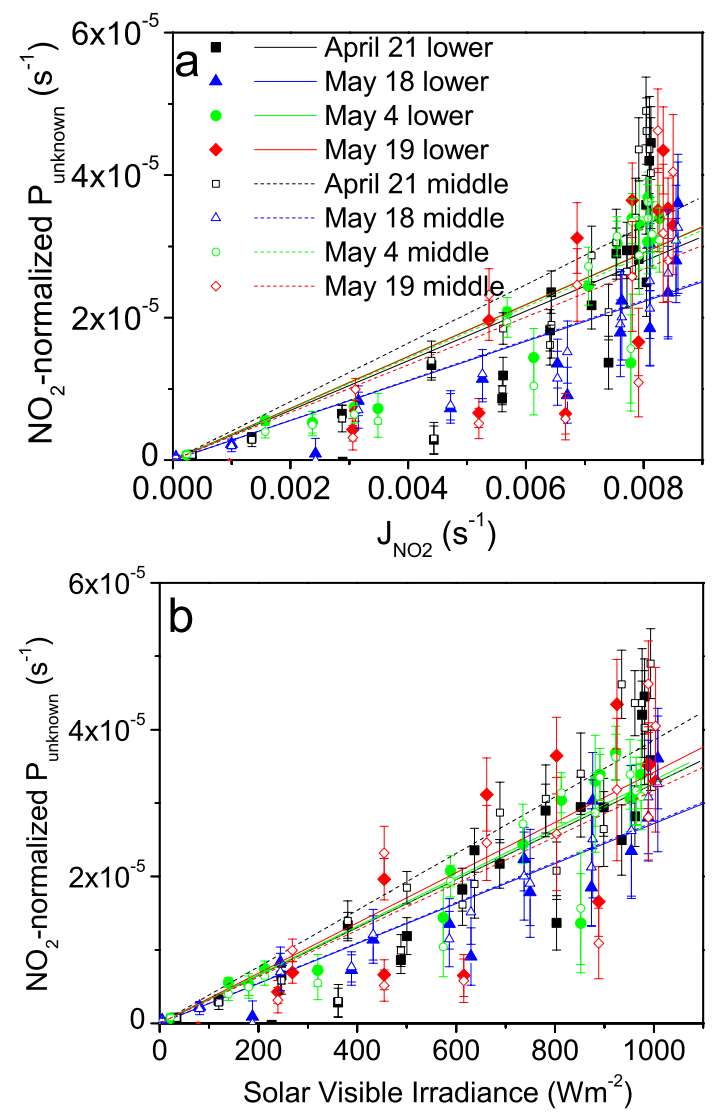

Fig. 8. Correlations of the $\mathrm{NO}_{2}$-normalized $\mathrm{P}_{\text {unknown }}$ with $J_{\mathrm{NO}_{2}}$ (a) and solar irradiance (b) in the lower and middle height intervals on four sunny days (21 April, 4 May, 18 and 19 May) during SHARP 2009. Results of the linear fits are shown in Table 1.

observed during SHARP had strong diurnal variations. It has also been suggested that photolysis of aerosol nitrate could lead to HONO formation. However, to explain our results this would require that the product of aerosol nitrate and aerosol surface area concentration would be well correlated with $\mathrm{NO}_{2}$. The correlation of this product and $\mathrm{NO}_{2}$ (not shown) was poor during our study, with $R^{2}$ between 0 and 0.1 . These considerations show that aerosol processes were not the main source of HONO.

The second argument to distinguish ground from aerosol mediated $\mathrm{NO}_{2}$ to $\mathrm{HONO}$ conversion is to investigate the correlation of $\mathrm{P}_{\text {norm }}$ with actinic flux and solar irradiance. Aerosol mediated conversion should functionally depend on the actinic flux, while conversion on the ground primarily depends on the solar irradiance at the ground. The difference between these two dependencies is based on the different geometries of illumination. The actinic flux integrates solar irradiance onto an air parcel from all directions, and thus shows a weaker solar zenith angle/temporal dependence than ground solar irradiance on a sunny day, which is proportional to cosine(solar zenith angle) ${ }^{-1}$. Figure 6 shows that 
Table 1. Linear fit results of Fig. 8.

\begin{tabular}{|c|c|c|c|c|c|c|c|}
\hline \multirow[t]{2}{*}{ Date } & \multirow{2}{*}{$\begin{array}{l}\text { Light } \\
\text { path }\end{array}$} & \multicolumn{2}{|c|}{$J_{\mathrm{NO}_{2}}$} & \multicolumn{2}{|c|}{ vis irradiance } & \multicolumn{2}{|c|}{ UV irradiance } \\
\hline & & $\begin{array}{l}\text { Slope } \\
\left(10^{-3}\right)\end{array}$ & $R^{2}$ & $\begin{array}{l}\text { Slope } \\
\left(10^{-8} \mathrm{~m}^{2}\right. \\
\left.\mathrm{W}^{-1} \mathrm{~s}^{-1}\right)\end{array}$ & $R^{2}$ & $\begin{array}{l}\text { Slope } \\
\left(10^{-7} \mathrm{~m}^{2}\right. \\
\left.\mathrm{W}^{-1} \mathrm{~s}^{-1}\right)\end{array}$ & $R^{2}$ \\
\hline \multirow{2}{*}{$4 / 21$} & lower & $3.5 \pm 0.3$ & 0.72 & $3.2 \pm 0.2$ & 0.86 & $6.7 \pm 0.4$ & 0.87 \\
\hline & middle & $4.1 \pm 0.4$ & 0.76 & $3.8 \pm 0.2$ & 0.90 & $7.9 \pm 0.4$ & 0.91 \\
\hline \multirow{2}{*}{$5 / 4$} & lower & $3.6 \pm 0.2$ & 0.82 & $3.3 \pm 0.2$ & 0.90 & $6.6 \pm 0.3$ & 0.93 \\
\hline & middle & $3.6 \pm 0.2$ & 0.82 & $3.3 \pm 0.2$ & 0.90 & $6.5 \pm 0.3$ & 0.93 \\
\hline \multirow{2}{*}{$5 / 18$} & lower & $2.8 \pm 0.2$ & 0.82 & $2.8 \pm 0.2$ & 0.89 & $5.5 \pm 0.2$ & 0.90 \\
\hline & middle & $2.9 \pm 0.2$ & 0.89 & $2.8 \pm 0.1$ & 0.96 & $6.5 \pm 0.2$ & 0.97 \\
\hline \multirow{2}{*}{$5 / 19$} & lower & $3.6 \pm 0.5$ & 0.70 & $3.6 \pm 0.3$ & 0.72 & $6.7 \pm 0.7$ & 0.75 \\
\hline & middle & $3.3 \pm 0.5$ & 0.58 & $3.2 \pm 0.4$ & 0.65 & $6.3 \pm 0.8$ & 0.70 \\
\hline \multicolumn{2}{|c|}{ Average } & $3.4 \pm 0.3$ & 0.76 & $3.3 \pm 0.2$ & 0.85 & $6.6 \pm 0.4$ & 0.87 \\
\hline
\end{tabular}

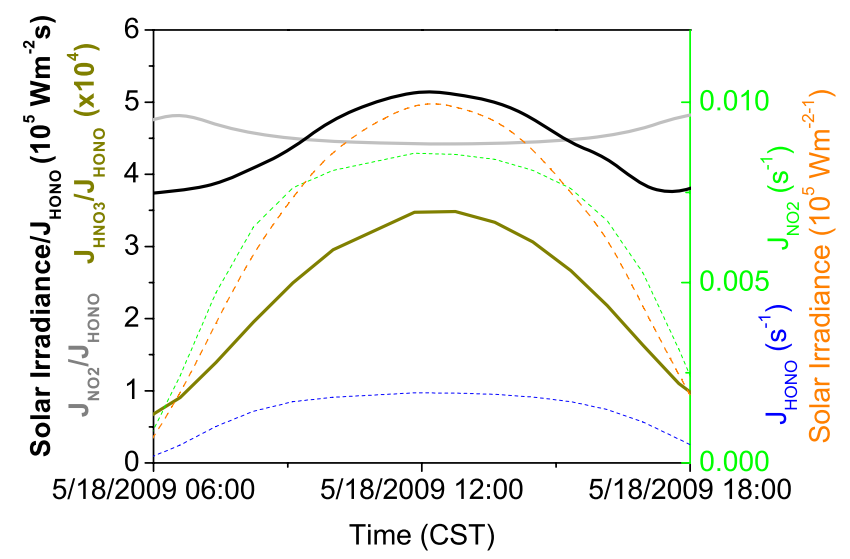

Fig. 9. Timeseries of solar irradiance, $J_{\mathrm{NO}_{2}}, J_{\mathrm{HONO}}$ and the ratios of solar irradiance $/ J_{\mathrm{NO}_{2}}, J_{\mathrm{HNO} 3} / J_{\mathrm{HONO}}$ and $J_{\mathrm{NO}_{2}} / J_{\mathrm{HONO}}$ on 18 May 2009, a clear and sunny day.

the measured diurnal profile of $J_{\mathrm{NO}_{2}}$, as a proxy for the actinic flux in the $300-450 \mathrm{~nm}$ region, and solar irradiance have indeed different diurnal profiles. One would thus expect that $\mathrm{P}_{\text {norm }}$ is better correlated with the actinic flux than solar irradiance for a conversion on the aerosol and vice-versa for a conversion on the ground. It should be noted however, that there is a certain degree of correlation between actinic flux and solar irradiance, and that $\mathrm{P}_{\text {norm }}$ will thus correlate with both quantities.

On 21 April, $\mathrm{P}_{\text {norm }}$ showed positive correlations with $J_{\mathrm{NO}_{2}}$, as a proxy for actinic flux, in lower and middle height intervals (Fig. 8a), with an $R^{2}$ of 0.72 and 0.76 and slopes of $(3.5 \pm 0.3) \times 10^{-3}$ and $(4.1 \pm 0.4) \times 10^{-3}$, respectively. The correlations were better on 18 May, with $R^{2}$ of 0.82 and 0.89 and slopes of $(2.8 \pm 0.2) \times 10^{-3}$ and $(2.9 \pm 0.2) \times 10^{-3}$ for the lower and middle height intervals, respectively. 4 and 19 May, also showed positive correlations (Fig. 8a). The correlation coefficient and slopes are summarized in Table 1. Cor- relations between the $\mathrm{P}_{\text {norm }}$ and solar irradiance in the visible wavelength region (400-700 nm) are shown in Fig. 8b. All four days showed significantly improved correlations between $\mathrm{P}_{\text {norm }}$ and visible solar irradiance compared to $J_{\mathrm{NO}_{2}}$ (Table 1). For example, $R^{2}$ improved from 0.72 and 0.76 on the lower and middle light path, respectively, to 0.86 and 0.90 on 21 April. The correlations increased on the other days as well, with the best correlation between $\mathrm{P}_{\text {norm }}$ and visible solar irradiance of 0.96 found on 18 May in the middle height interval. A visual comparison of Fig. 8a and b reveals that the improved correlation stems from a better linearity between the $\mathrm{P}_{\text {norm }}$ and solar irradiance. All four days showed similar slopes, from $(2.8 \pm 0.2) \times 10^{-8} \mathrm{~m}^{2} \mathrm{~W}^{-1} \mathrm{~s}^{-1}$ to $(3.8 \pm 0.2) \times 10^{-8} \mathrm{~m}^{2} \mathrm{~W}^{-1} \mathrm{~s}^{-1}$. We repeated this correlation analysis for solar UV irradiance $(290-385 \mathrm{~nm})$. In all instances (Table 1), the correlation with UV solar irradiance was also better than with $J_{\mathrm{NO}_{2}}$. A comparison of the correlations with UV and visible solar irradiance showed that all days showed better correlation in the UV.

The average correlation coefficient on all four days in both height intervals improved from $R^{2}=0.76$ with $J_{\mathrm{NO}_{2}}$ to $0.85 / 0.87$ with solar UV/visible irradiance. The improved correlations of the unknown HONO formation rate with solar irradiance suggested that $\mathrm{NO}_{2}$ to $\mathrm{HONO}$ on the ground was the most likely source of HONO in Houston.

The third approach to investigate the potential HONO formation mechanism on the aerosol vs. the ground is based on the observed $[\mathrm{HONO}] /\left[\mathrm{NO}_{2}\right]$ ratio (Eq. 6). As described above, if $\mathrm{NO}_{2}$ to $\mathrm{HONO}$ conversion occurs on the aerosol it will depend on $J_{\text {source }} \cdot\left[\mathrm{NO}_{2}\right]$ (where $J_{\text {source }}$ is a proxy for the actinic flux), and the $\mathrm{HONO}$ to $\mathrm{NO}_{2}$ ratio will be proportional to the ratio of $J_{\text {source }}$ and $J_{\text {HONO. In the case of }}$ $J_{\text {source }}=J_{\mathrm{NO}_{2}}$ this ratio is almost constant throughout the day (Fig. 9). 

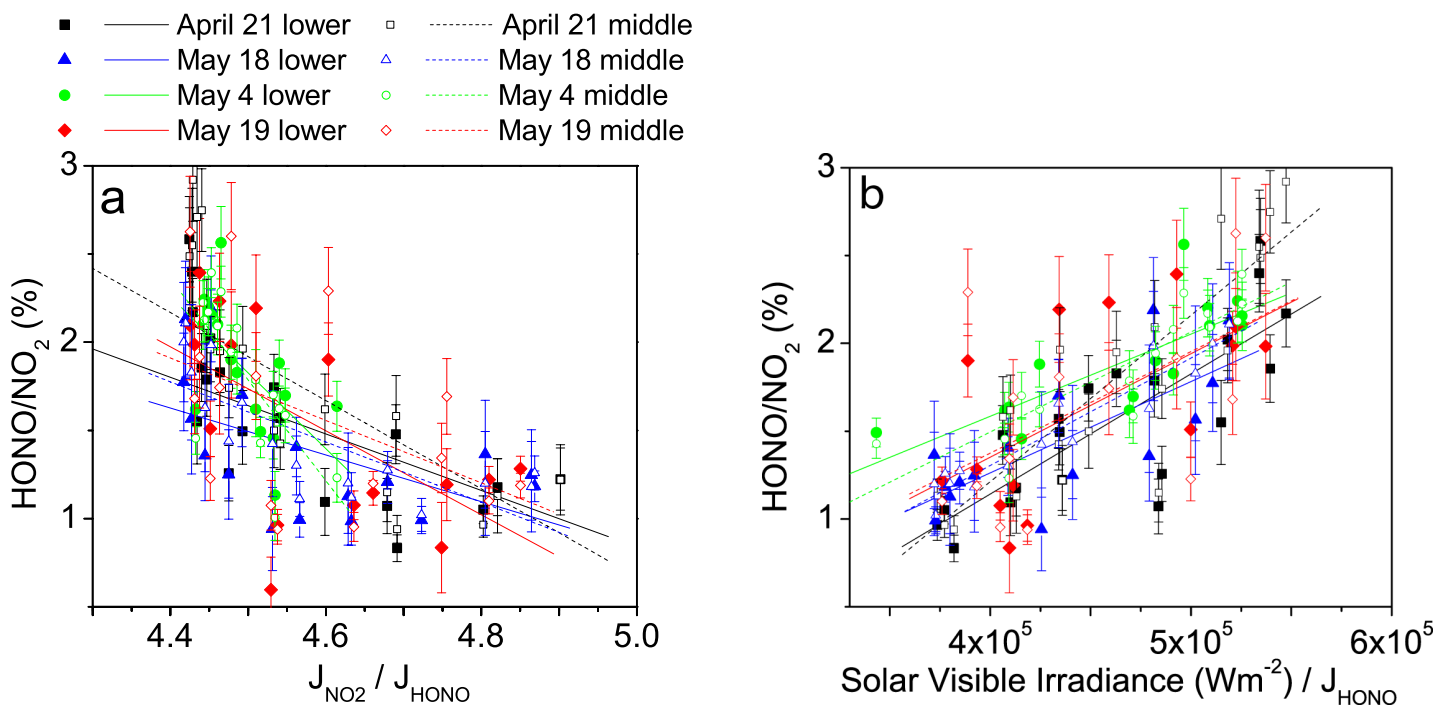

Fig. 10. Correlations of the adjusted $\mathrm{HONO}$ to $\mathrm{NO}_{2}$ ratios with $J_{\mathrm{NO}_{2}} / J_{\mathrm{HONO}}$ ratio (a) and solar visible irradiance/ $J_{\mathrm{HONO}}(\mathbf{b})$ on four sunny days (21 April, 4, 18 and 19 May) during SHARP 2009.

Table 2. Linear fit results of Fig. 10.

\begin{tabular}{|c|c|c|c|c|c|c|c|c|c|c|}
\hline \multirow[t]{2}{*}{ Date } & \multirow{2}{*}{$\begin{array}{l}\text { Light } \\
\text { path }\end{array}$} & \multicolumn{3}{|c|}{$J_{\mathrm{NO}_{2}} / J_{\mathrm{HONO}}$} & \multicolumn{3}{|c|}{ vis irradiance $/ J_{\mathrm{HONO}}$} & \multicolumn{3}{|c|}{ UV irradiance $/ J_{\mathrm{HONO}}$} \\
\hline & & Intercept (\%) & Slope $(\%)$ & $R^{2}$ & Intercept $(\%)$ & $\begin{array}{l}\text { Slope } \\
\left(10^{-6} \%\right. \\
\left.\mathrm{m}^{2} \mathrm{~W}^{-1} \mathrm{~s}^{-1}\right)\end{array}$ & $R^{2}$ & Intercept $(\%)$ & $\begin{array}{l}\text { Slope } \\
\left(10^{-5} \%\right. \\
\left.\mathrm{m}^{2} \mathrm{~W}^{-1} \mathrm{~s}^{-1}\right)\end{array}$ & $R^{2}$ \\
\hline \multirow[t]{2}{*}{$4 / 21$} & lower & $8.9 \pm 2.7$ & $-1.6 \pm 0.6$ & 0.25 & $-1.6 \pm 0.6$ & $6.8 \pm 1.2$ & 0.65 & $0.11 \pm 0.25$ & $7.1 \pm 1.2$ & 0.57 \\
\hline & middle & $13 \pm 3.2$ & $-2.5 \pm 0.7$ & 0.41 & $-2.6 \pm 0.6$ & $9.5 \pm 1.3$ & 0.75 & $-0.26 \pm 0.25$ & $10 \pm 1.2$ & 0.81 \\
\hline \multirow[t]{2}{*}{$5 / 4$} & lower & $21 \pm 6.9$ & $-4.3 \pm 1.5$ & 0.36 & $-0.29 \pm 0.4$ & $4.7 \pm 0.8$ & 0.71 & $-0.39 \pm 0.56$ & $9.5 \pm 2.4$ & 0.54 \\
\hline & middle & $28 \pm 6.8$ & $-5.7 \pm 1.5$ & 0.51 & $-0.78 \pm 0.3$ & $5.7 \pm 0.7$ & 0.84 & $-0.92 \pm 0.55$ & $12 \pm 2.3$ & 0.64 \\
\hline \multirow[t]{2}{*}{$5 / 18$} & lower & $7.5 \pm 2.5$ & $-1.3 \pm 0.5$ & 0.29 & $-0.81 \pm 0.6$ & $5.2 \pm 1.3$ & 0.55 & $0.43 \pm 0.32$ & $5.0 \pm 1.5$ & 0.47 \\
\hline & middle & $9.3 \pm 1.7$ & $-1.7 \pm 0.4$ & 0.57 & $-1.1 \pm 0.2$ & $6.1 \pm 0.5$ & 0.91 & $0.29 \pm 0.15$ & $6.0 \pm 0.7$ & 0.85 \\
\hline \multirow[t]{2}{*}{$5 / 19$} & lower & $12 \pm 3.9$ & $-2.4 \pm 0.8$ & 0.36 & $-1.0 \pm 0.1$ & $5.9 \pm 2.1$ & 0.39 & $0.11 \pm 0.46$ & $7.3 \pm 2.1$ & 0.50 \\
\hline & middle & $9.7 \pm 4.2$ & $-1.8 \pm 0.9$ & 0.21 & $-0.93 \pm 0.1$ & $5.8 \pm 2.4$ & 0.33 & $0.14 \pm 0.51$ & $7.2 \pm 2.4$ & 0.43 \\
\hline \multicolumn{2}{|c|}{ Average } & $14 \pm 4$ & $-2.7 \pm 0.9$ & 0.37 & $-1.2 \pm 0.4$ & $6.2 \pm 1.3$ & 0.64 & $-0.06 \pm 0.4$ & $8.0 \pm 1.7$ & 0.60 \\
\hline
\end{tabular}

$$
\frac{d[\mathrm{HONO}]}{d t}=P_{\mathrm{unknown}}-J_{\mathrm{HONO}}[\mathrm{HONO}]
$$

If $P_{\text {unknown }} \propto J_{\text {source }} \cdot\left[\mathrm{NO}_{2}\right]$ then : $\frac{[\mathrm{HONO}]}{\left[\mathrm{NO}_{2}\right]} \propto \frac{J_{\text {source }}}{J_{\mathrm{HONO}}}$

If $P_{\text {unknown }} \propto$ solar irradiance $\cdot\left[\mathrm{NO}_{2}\right]$ then :

$$
\frac{[\mathrm{HONO}]}{\left[\mathrm{NO}_{2}\right]} \propto \frac{\text { solar irradiance }}{J_{\mathrm{HONO}}}
$$

The correlation between $[\mathrm{HONO}] /\left[\mathrm{NO}_{2}\right]$ and $J_{\mathrm{NO}_{2}} / J_{\mathrm{HONO}}$ in Fig. 10a clearly shows that these two quantities are not well correlated. $R^{2}$ for all four days varied between 0.21 and 0.57 , with an average $R^{2}=0.37$ (Table 2). Consequently, $\mathrm{NO}_{2}$ to HONO conversion on aerosol that is photoenhanced by solar irradiance in the $300-450 \mathrm{~nm}$ range and other longer wavelengths cannot explain the observed diurnal pattern of the HONO to $\mathrm{NO}_{2}$ ratio (Figs. $3 \mathrm{~g}$ and $4 \mathrm{~g}$ ). If the absorption wavelengths of $J_{\text {source }}$ are further in the UV than the absorption of HONO, and in particular below $345 \mathrm{~nm}$, the absorption of atmospheric ozone will introduce another factor modulating the actinic flux which can lead to a diurnal dependence of $J_{\text {source }} / J_{\mathrm{HONO}}$.

On the other hand, if $\mathrm{NO}_{2}$ to $\mathrm{HONO}$ conversion occurs primarily at the ground, so that it depends on solar irradiance, the $\mathrm{HONO}$ to $\mathrm{NO}_{2}$ ratio should be proportional to the ratio of solar irradiance to $J_{\mathrm{HONO}}$, which shows a clear diurnal variation, peaking at noontime (Fig. 9). Correlations of $[\mathrm{HONO}] /\left[\mathrm{NO}_{2}\right]$ and the ratio of visible solar irradiance to $J_{\text {HONO }}$ are shown in Fig. 10 b. $R^{2}$ range from 0.33 to 0.91 
with an overall $R^{2}=0.64$ (Table 2). Slopes varied from 5$10 \times 10^{-6} \% \mathrm{~m}^{2} \mathrm{~W}^{-1} \mathrm{~s}^{-1}$. This positive correlation and the fairly constant slope further strengthens our reasoning that $\mathrm{NO}_{2}$ to HONO photolytic conversion at the ground is the main source of daytime HONO in Houston.

Proposed daytime HONO formation pathways that occur on the ground include the photolysis of $\mathrm{HNO}_{3}, \mathrm{NO}_{2}$ conversion on humic acid and HONO formation from soil nitrite (Zhou et al., 2003; Stemmler et al., 2006; Su et al., 2011). While our analysis cannot clearly distinguish these pathways, the dependence of $\mathrm{HONO}$ formation on $\mathrm{NO}_{2}$ observed in Houston seems to favor $\mathrm{NO}_{2}$ conversion on humic acid. For $\mathrm{HNO}_{3}$ photolysis to be the main source it would be required that $\mathrm{HNO}_{3}$ at the ground is well correlated with gas-phase $\mathrm{NO}_{2}$. We do not have information on ground surface $\mathrm{HNO}_{3}$, but observations of particle nitrate do not correlate well with $\mathrm{NO}_{2}$ on all days (for example $R^{2}=0$ on 21 April in the lower and middle interval). It can thus be reasoned that a correlation of ground surface $\mathrm{HNO}_{3}$ and $\mathrm{NO}_{2}$ is unlikely. $\mathrm{HONO}$ formation from soil nitrite is not shown to be dependent on gas-phase $\mathrm{NO}_{2}$ concentration, but on nitrite concentration in the soil, which depends on soil acidity and temperature (Su et al., 2011). We do not have sufficient data to evaluate if soil nitrite can be the daytime HONO source.

The fourth approach of determining the source of HONO is to interpret HONO vertical gradients. If $\mathrm{HONO}$ formation occurs at the ground, HONO mixing ratios should be larger near the ground than aloft. If HONO formation occurs on the aerosol surface instead, HONO vertical profiles should follow the aerosol surface area concentration and $\mathrm{NO}_{2}$ profiles. For example, if the aerosol surface area concentration profile is constant and the $\mathrm{NO}_{2}$ profile shows larger concentrations near the ground than aloft, HONO mixing ratios are expected to be greater near the ground than aloft as well. On the other hand, if the $\mathrm{NO}_{2}$ concentration profile is uniform and the aerosol surface area concentrations are higher near the ground than aloft, HONO would also be higher near the ground. The interpretation of HONO vertical profiles thus becomes more complex if both $\mathrm{NO}_{2}$ and aerosol surface area concentrations develop vertical profiles.

As shown in Figs. 3 and $4, \mathrm{NO}_{2}$ mixing ratios showed clear vertical concentration profiles, with higher levels near the ground. The HONO profiles closely follow the $\mathrm{NO}_{2}$ profiles, as can be seen by the absence of a vertical profile in the $[\mathrm{HONO}] /\left[\mathrm{NO}_{2}\right]$ ratio. A uniform aerosol surface area concentration profile and the conversion of $\mathrm{NO}_{2}$ to $\mathrm{HONO}$ on the aerosol surface would thus appear to describe our observations of daytime HONO. We thus investigated the aerosol vertical distribution on the two sunny days shown in Figs. 3 and 4. Timeseries of ceilometer laser backscatter values on both days are shown in Fig. 11. The backscatter signal on both days does not show strong vertical gradients but, as this instrument is not very accurate in the determination of aerosol profiles, it is difficult to rule out aerosol gradients altogether. On the other hand, profiles of aerosols, which

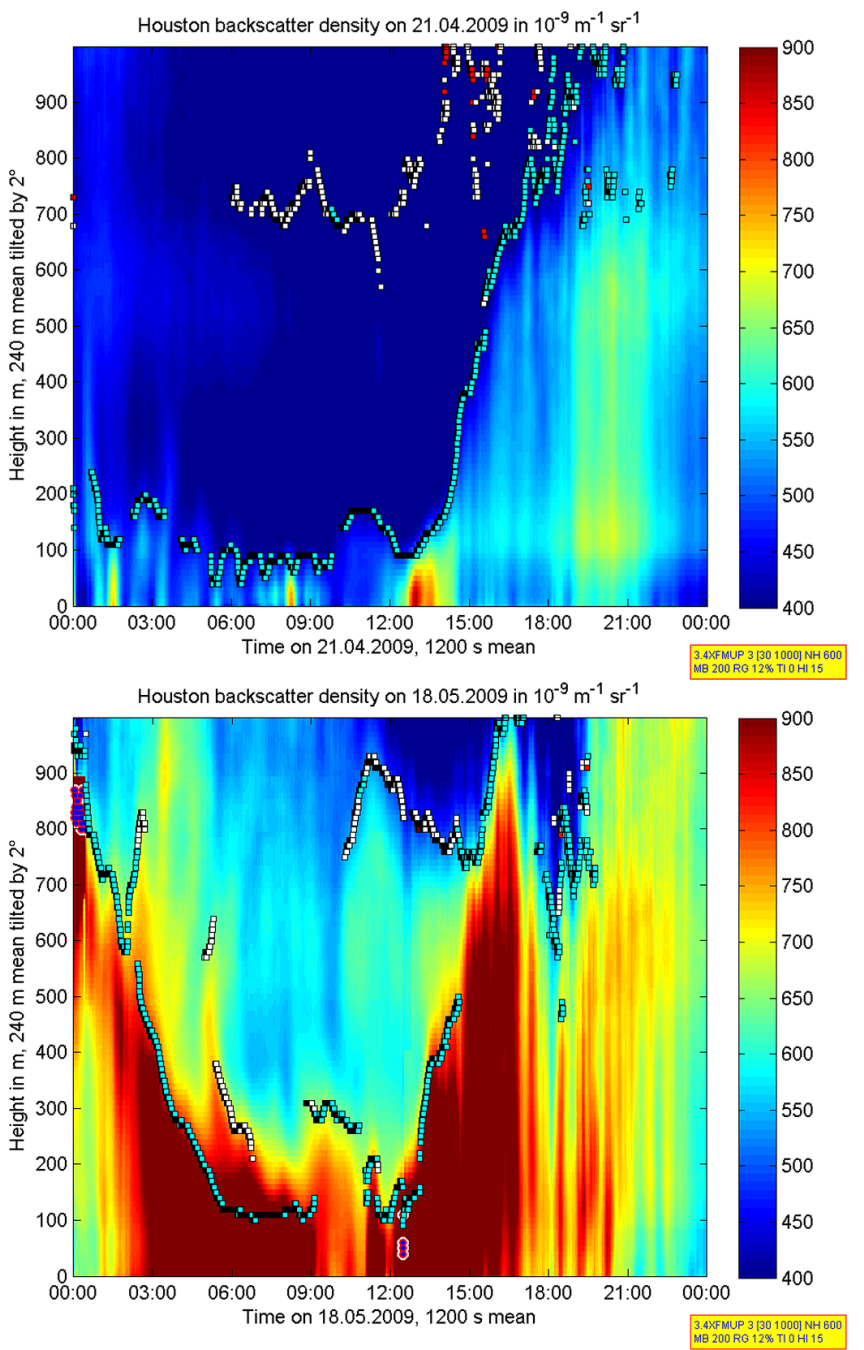

Fig. 11. Timeseries of lidar aerosol backscatter on 21 April 2009 (top) and 18 May 2009 (bottom) measured by a ceilometer.

have atmospheric lifetimes of days to weeks, are expected to be well mixed in the daytime boundary layer and their gradients should be small. Based on these arguments alone photo-enhanced conversion of $\mathrm{NO}_{2}$ to $\mathrm{HONO}$ seems to be a feasible explanation for the observed daytime HONO. Although the use of vertical $\mathrm{HONO}$ and $\mathrm{NO}_{2}$ profiles has been inconclusive, our previous three analyses clearly showed that the ground is the source of $\mathrm{P}_{\text {unknown }}$.

\section{Conclusions}

During SHARP 2009, HONO mixing ratios decreased rapidly after sunrise due to photolysis and mixing of the boundary layer. However, on most of the days, HONO mixing ratios were higher than the photostationary state mixing ratios calculated based on direct observations of $\mathrm{OH}, \mathrm{NO}$, and $J_{\mathrm{HONO}}$, which implied that an unknown source of HONO 
existed during the day. HONO developed negative concentration gradients, with higher mixing ratios near the ground than aloft, not only in the morning when the atmosphere was still stable, but also frequently in the late morning and in the afternoon when the boundary layer was expected to be wellmixed. Existence of HONO vertical gradients suggested that there was a strong source of HONO near the ground. The observed $[\mathrm{HONO}] /\left[\mathrm{NO}_{2}\right]$ ratio showed a diurnal variation peaking at noon almost every day during the field experiment, indicating the unknown HONO source, $\mathrm{P}_{\text {unknown }}$, was photolytic.

Our observations are similar to those previously reported in urban areas (Villena et al., 2011; Elshorbany et al., 2009; Acker et al., 2006a) and in semi-rural to remote areas (Sörgel et al., 2011a,b; Zhang et al., 2009; Su et al., 2008; Ren et al., 2010, 2011; Acker et al., 2006b; Kleffmann et al., 2005; Zhou et al., 2002). However, our mixing ratios are on the lower end of the thus far observed daytime HONO mixing ratios in urban areas. The diurnal variation of the $[\mathrm{HONO}] /\left[\mathrm{NO}_{2}\right]$ ratio are similar to those reported in other urban areas (Acker et al., 2006a; Villena et al., 2011; Elshorbany et al., 2009), but differ from those in rural and forested areas, which in general do not show a clear diurnal variation or a peak at noon (for example Zhou et al., 2007; Ren et al., 2010). Our observations of elevated HONO near the ground agree with previous reports by Zhou et al. (2001); Kleffmann (2007); Zhang et al. (2009); Villena et al. (2011).

The $\mathrm{NO}_{2}$-normalized $\mathrm{P}_{\text {unknown }}, \mathrm{P}_{\text {norm }}$, had clear symmetrical diurnal variation with maximum at noon on all four sunny days. Correlation analysis further confirmed that $\mathrm{P}_{\text {norm }}$ was indeed correlated with actinic flux and solar irradiance. Our $\mathrm{P}_{\text {unknown }}$ values for the four sunny days analyzed here (diurnal maximum 5-9 $\times 10^{6} \mathrm{~cm}^{-3} \mathrm{~s}^{-1}$ ) are smaller than reports from polluted areas such as polluted rural site (up to $3 \times 10^{7} \mathrm{~cm}^{-3} \mathrm{~s}^{-1}$ ) (Su et al., 2008) and an urban area (up to $1.2 \times 10^{7} \mathrm{~cm}^{-3} \mathrm{~s}^{-1}$ ) (Elshorbany et al., 2009), but larger than the HONO formation rate reported in semi rural forest (up to $3.5 \times 10^{6} \mathrm{~cm}^{-3} \mathrm{~s}^{-1}$ ) (Kleffmann et al., 2005) and a rural mountain (up to $4 \times 10^{6} \mathrm{~cm}^{-3} \mathrm{~s}^{-1}$ ) (Acker et al., 2006b).

Analysis of the diurnal variations of $[\mathrm{HONO}] /\left[\mathrm{NO}_{2}\right]$ ratio and $\mathrm{P}_{\text {norm }}$ showed that HONO formation most likely occurred at the ground rather than on the aerosol or in the gasphase. The conclusion that HONO is formed at the ground is supported by various studies. Laboratory studies suggested that $\mathrm{NO}_{2}$ conversion at the ground can be an important source of daytime HONO (Stemmler et al., 2006). However, their studies on aerosol showed that formation of HONO on aerosol was unimportant due to the small uptake coefficient of $\mathrm{NO}_{2}$ (Stemmler et al., 2007). Aircraft vertical profile HONO measurements showing higher HONO concentration near the ground than aloft suggested that a photolytic source at the ground was the dominant daytime HONO source in the lower boundary layer (Zhang et al., 2009). Flux measurements showed that photolysis in the snow pack lead to the formation of HONO (Zhou et al., 2001). The same group recently performed measurement over a forest canopy and found a dependence of the HONO flux on solar radiation (Zhou et al., 2011).

While it is difficult to identify the chemical formation mechanisms that lead to HONO formation, the close correlation of $\mathrm{HONO}$ formation with $\mathrm{NO}_{2}$ appears to favor photo-enhanced $\mathrm{NO}_{2}$ conversion on humic acid, as proposed by Stemmler et al. (2006). Our results seem to be consistent with the observations by Sörgel et al. (2011b), who showed that photoexcited gas-phase $\mathrm{NO}_{2}$ was not the dominant source of daytime HONO. They identified $\mathrm{NO}_{2}$ conversion on humic acid covered surfaces as the most likely source, although there was insufficient information about the surface on which the reaction primarily occurred (Sörgel et al., 2011b). Our results showed that it is also possible that photolysis of adsorbed nitric acid at the ground and soil nitrite could be important sources.

Our results, which are based on spatially averaged HONO measurements, seem to indicate an easy way to parameterize daytime HONO formation in the Houston area during a sunny day. Based on the correlations with $\left[\mathrm{NO}_{2}\right]$ and solar irradiance we propose the following formation term for the lowest $130 \mathrm{~m}$ of the Houston atmosphere: $\mathrm{P}_{\text {unknown }}=(3.3 \pm 0.2) 10^{-8} \mathrm{~m}^{2} \mathrm{~W}^{-1} \mathrm{~s}^{-1}$. solar visible irradiance $\cdot\left[\mathrm{NO}_{2}\right]$ or $\mathrm{P}_{\text {unknown }}=(6.6 \pm 0.4) 10^{-7} \mathrm{~m}^{2} \mathrm{~W}^{-1} \mathrm{~s}^{-1} \cdot$ solar UV irradiance $\cdot\left[\mathrm{NO}_{2}\right]$. Whether this formation term holds for other locations and whether it will lead to an improvement of photochemical models in the Houston area should be the topic of further investigations.

Acknowledgements. This work was funded by the State of Texas through the Texas Commission of Environmental Quality, the Houston Advanced Research Center, and the Air Quality Research Program of the University of Texas. Funding was also provided by the National Science Foundation (NSF) Career Award.

Edited by: I. Trebs

\section{References}

Acker, K., Febo, A., Trick, S., Perrino, C., Bruno, P., Wiesen, P., Moller, D., Wieprecht, W., Auel, R., Giusto, M., Geyer, A., Platt, U., and Allegrini, I.: Nitrous acid in the urban area of Rome, Atmos. Environ., 40, 3123-3133, doi:10.1016/j.atmosenv.2006.01.028, 2006a.

Acker, K., Moller, D., Wieprecht, W., Meixner, F., Bohn, B., Gilge, S., Plass-Dulmer, C., and Berresheim, H.: Strong daytime production of $\mathrm{OH}$ from $\mathrm{HNO}_{2}$ at a rural mountain site, Geophys. Res. Lett., 33, L02809, doi:10.1029/2005GL024643, 2006 b.

Alicke, B., Platt, U., and Stutz, J.: Impact of nitrous acid photolysis on the total hydroxyl radical budget during the Limitation of Oxidant Production/Pianura Padana Produzione di Ozono study in Milan, J. Geophys. Res., 107, 8196, doi:10.1029/2000JD000075, 2002.

Alicke, B., Geyer, A., Hofzumahaus, A., Holland, F., Konrad, S., Patz, H., Schafer, J., Stutz, J., Volz-Thomas, A., 
and Platt, U.: OH formation by HONO photolysis during the BERLIOZ experiment, J. Geophys. Res.-Atmos., 108, 8247, doi:10.1029/2001JD000579, 2003.

Amedro, D., Parker, A., Schoemaecker, C., and Fittschen, C.: Direct observation of $\mathrm{OH}$ radicals after $565 \mathrm{~nm}$ multiphoton excitation of $\mathrm{NO}_{2}$ in the presence of $\mathrm{H}_{2} \mathrm{O}$, Chem. Phys. Lett., 513, 12-16, doi:10.1016/ j.cplett.2011.07.062, 2011.

Aumont, B., Chervier, F., and Laval, S.: Contribution of HONO sources to the $\mathrm{NO}_{\mathrm{x}} / \mathrm{HO}_{\mathrm{x}} / \mathrm{O}_{3}$ chemistry in the polluted boundary layer, Atmos. Environ., 37, 487-498, 2003.

Beine, H., Domine, F., Simpson, W., Honrath, R., Sparapani, R., Zhou, X., and King, M.: Snow-pile and chamber experiments during the Polar Sunrise Experiment "Alert 2000": exploration of nitrogen chemistry, Atmos. Environ., 36, 2707-2719, doi:10.1016/S1352-2310(02)00120-6, 2002.

Bejan, I., Abd El Aal, Y., Barnes, I., Benter, T., Bohn, B., Wiesen, P., and Kleffmann, J.: The photolysis of ortho-nitrophenols: a new gas phase source of HONO, Phys. Chem. Chem. Phys., 8, 2028-2035, doi:10.1039/b516590c, 2006.

Carr, S., Heard, D., and Blitz, M.: Comment on "Atmospheric Hydroxyl Radical Production from Electronically Excited $\mathrm{NO}_{2}$ and $\mathrm{H}_{2} \mathrm{O}$ ”, Science, 324, 5925, doi:10.1126/science.1166669, 2009.

Crowley, J. and Carl, S.: OH formation in the photoexcitation of $\mathrm{NO}_{2}$ beyond the dissociation threshold in the presence of water vapor, J. Phys. Chem. A., 101, 4178-4184, doi:10.1021/jp970319e, 1997.

Dibb, J., Arsenault, M., Peterson, M., and Honrath, R.: Fast nitrogen oxide photochemistry in Summit, Greenland snow, Atmos. Environ., 36, 2501-2511, doi:10.1016/S1352-2310(02)00130-9, 2002.

Elshorbany, Y., Kurtenbach, R., Wiesen, P., Lissi, E., Rubio, M., Villena, G., Gramsch, E., Rickard, A., Pilling, M., and Kleffmann, J.: Oxidation capacity of the city air of Santiago, Chile, Atmos. Chem. Phys., 9, 2257-2273, doi:10.5194/acp-9-22572009, 2009.

Ensberg, J., Carreras-Sospedra, M., and Dabdub, D.: Impacts of electronically photo-excited $\mathrm{NO}_{2}$ on air pollution in the South Coast Air Basin of California, Atmos. Chem. Phys., 10, 11711181, doi:10.5194/acp-10-11771-2010, 2010.

Faloona, I., Tan, D., Lesher, R., Hazen, N., Frame, C., Simpas, J., Harder, H., Martinez, M., Di Carlo, P., Ren, X., and Brune, W.: A laser-induced fluorescence instrument for detecting tropospheric $\mathrm{OH}$ and $\mathrm{HO}_{2}$ : Characteristics and calibration, J. Atmos. Chem., 47, 139-167, doi:10.1023/B:JOCH.0000021036.53185.0e, 2004.

Finlayson-Pitts, B., Wingen, L., Sumner, A., Syomin, D., and Ramazan, K.: The heterogeneous hydrolysis of $\mathrm{NO}_{2}$ in laboratory systems and in outdoor and indoor atmospheres: An integrated mechanism, Phys. Chem. Chem. Phys., 5, 223-242, doi:10.1039/b208564j, 2003.

George, C., Strekowski, R., Kleffmann, J., Stemmler, K., and Ammann, M.: Photoenhanced uptake of gaseous $\mathrm{NO}_{2}$ on solidorganic compounds: a photochemical source of HONO?, Faraday Discuss., 130, 195-210, doi:10.1039/b417888m, 2005.

Harrison, M., Barra, S., Borghesi, D., Vione, D., Arsene, C., and Olariu, R.: Nitrated phenols in the atmosphere: a review, Atmos. Environ., 39, 231-248, doi:10.1016/j.atmosenv.2004.09.044, 2005.

Hseler, R., Brauers, T., Holland, F., and Wahner, A.: Develop- ment and application of a new mobile LOPAP instrument for the measurement of HONO altitude profiles in the planetary boundary layer, Atmos. Meas. Tech. Discuss., 2, 2027-2054, doi:10.5194/amtd-2-2027-2009, 2009.

He, Y., Zhou, X., Hou, J., Gao, H., and Bertman, S.: Importance of dew in controlling the air-surface exchange of HONO in rural forested environments, Geophys. Res. Lett., 33, L02813, doi:10.1029/2005GL024348, 2006.

Kessler, C. and Platt, U.: Nitrous acid in polluted air masses - Sources and formation pathways, in: Physico-chemical Behaviour of Atmospheric Pollutants (Proceedings), edited by: Versino, B. and Angeletti, G., D. Reidel, Dordrecht, The Netherlands, 412-422, 1984.

Kirchstetter, T., Harley, R., and Littlejohn, D.: Measurement of nitrous acid in motor vehicle exhaust, Environ. Sci. Technol., 30, 2843-2849, 1996.

Kleffmann, J.: Daytime sources of nitrous acid (HONO) in the atmospheric boundary layer, Chem. Phys. Chem., 8, 1137-1144, doi:10.1002/cphc.200700016, 2007.

Kleffmann, J., Kurtenbach, R., Lorzer, J., Wiesen, P., Kalthoff, N., Vogel, B., and Vogel, H.: Measured and simulated vertical profiles of nitrous acid - Part I: Field measurements, Atmos. Environ., 37, 2949-2955, doi:10.1016/S1352-2310(03)00242-5, 2003.

Kleffmann, J., Gavriloaiei, T., Hofzumahaus, A., Holland, F., Koppmann, R., Rupp, L., Schlosser, E., Siese, M., and Wahner, A.: Daytime formation of nitrous acid: A major source of $\mathrm{OH}$ radicals in a forest, Geophys. Res. Lett., 32, doi:10.1029/2005GL022524, 2005.

Kurtenbach, R., Becker, K., Gomes, J., Kleffmann, J., Lorzer, J., Spittler, M., Wiesen, P., Ackermann, R., Geyer, A., and Platt, U.: Investigations of emissions and heterogeneous formation of HONO in a road traffic tunnel, Atmos. Environ., 35, 3385-3394, 2001.

Lammel, G. and Cape, J.: Nitrous acid and nitrite in the atmosphere, Chem. Soc. Rev., 25, 361-369, 1996.

Lefer, B., Shetter, R., Hall, S., Crawford, J., and Olson, J.: Impact of clouds and aerosols on photolysis frequencies and photochemistry during TRACE-P: 1 . Analysis using radiative transfer and photochemical box models, J. Geophys. Res.-Atmos., 108, 8821, doi:10.1029/2002JD003171, 2003.

Lefer, B., Rappenglück, B., Flynn, J., and Haman, C.: Photochemical and meteorological relationships during the Texas-II Radical and Aerosol Measurement Project (TRAMP), Atmos. Environ., 44, 4005-4013, doi:10.1016/j.atmosenv.2010.03.011, 2010.

Li, S., Matthews, J., and Sinha, A.: Atmospheric hydroxyl radical production from electronically excited $\mathrm{NO}_{2}$ and $\mathrm{H}_{2} \mathrm{O}$, Science, 319, 1657-1660, doi:10.1126/science.1151443, 2008.

Li, S., Matthews, J., and Sinha, A.: Response to comment on "Atmospheric hydroxyl radical production from electronically excited $\mathrm{NO}_{2}$ and $\mathrm{H}_{2} \mathrm{O}$ ”, Science, 324, 336, doi:10.1126/science.1166877, 2009.

Luke, W., Arnold, J., Gunter, R., Watson, T., Wellman, D., Dasgupta, P., Li, J., Riemer, D., and Tate, P.: The NOAA Twin Otter and its role in BRACE: Platform description, Atmos. Environ., 41, 4177-4189, doi:10.1016/j.atmosenv.2006.09.055, 2007.

Luke, W., Kelley, P., Lefer, B., Flynn, J., Rappenglück, B., Leuchner, M., Dibb, J., Ziemba, L., Anderson, C., and Buhr, M.: Measurements of primary trace gases and $\mathrm{NO}_{\mathrm{y}}$ 
composition in Houston, Texas, Atmos. Environ., 44, 40684080, doi:10.1016/j.atmosenv.2009.08.014, 2010.

Mao, J., Ren, X., Chen, S. Brune, W., Chen, Z., Martinez, M., Harder, H., Lefer, B., Rappenglück, B., Flynn, J., and Leuchner, M.: Atmospheric oxidation capacity in the summer of Houston 2006: Comparison with summer measurements in other metropolitan studies, Atmos. Environ., 44, 4107-4115, doi:10.1016/j.atmosenv.2009.01.013, 2010.

Pitts, J., Biermann, H., Winer, A., and Tuazon, E.: Spectroscopic identification and measurement of gaseous nitrous-acid in dilute auto exhaust, Atmos. Environ., 18, 847-854, 1984.

Platt, U. and Stutz, J.: Differential Optical Absorption Spectroscopy: Principles and Applications, Springer, Berlin, Heidelberg, 1-597, doi:10.1007/978-3-540-75776-4, 2008.

Platt, U., Perner, D., Harris, G., Winer, A., and Pitts, J.: Observations of nitrous-acid in an urban atmosphere by differential optical-absorption, Nature, 285, 312-314, doi:10.1038/285312a0, 1980.

Ren, X., Gao, H., Zhou, X., Crounse, J., Wennberg, P., Browne, E., LaFranchi, B., Cohen, R., McKay, M., Goldstein, A., and Mao, J.: Measurement of atmospheric nitrous acid at Blodgett Forest during BEARPEX2007, Atmos. Chem. Phys., 10, 6283-6294, doi:10.5194/acp-10-6283-2010, 2010.

Ren, X., Sanders, J. E., Rajendran, A., Weber, R. J., Goldstein, A. H., Pusede, S. E., Browne, E. C., Min, K.-E., and Cohen, R. C.: A relaxed eddy accumulation system for measuring vertical fluxes of nitrous acid, Atmos. Meas. Tech., 4, 2093-2103, doi:10.5194/amt-4-2093-2011, 2011.

Sander, S., Friedl, R., Ravishankara, A., Golden, D., Kolb, C., Kurylo, M., Molina, M., Moortgat, G., Keller-Rudek, H., Finlayson-Pitts, B., Wine, P., Huie, R., and Orkin, V.: Chemical Kinetics and Photochemical Data for Use in Atmospheric Studies (Evaluation Number 15), JPL Publication, 2006.

Shetter, R., Cinquini, L., Lefer, B., Hall, S., and Madronich, S.: Comparison of airborne measured and calculated spectral actinic flux and derived photolysis frequencies during the PEM Tropics B mission, J. Geophys. Res.-Atmos., 108, 8234, doi:10.1029/2001JD001320, 2002.

Sörgel, M., Trebs, I., Serafimovich, A., Moravek, A., Held, A., and Zetzsch, C.: Simultaneous HONO measurements in and above a forest canopy: influence of turbulent exchange on mixing ratio differences, Atmos. Chem. Phys., 11, 841-855, doi:10.5194/acp11-841-2011, 2011a.

Sörgel, M., Regelin, E., Bozem, H., Diesch, J.-M., Drewnick, F., Fischer, H., Harder, H., Held, A., Hosaynali-Beygi, Z., Martinez, M., and Zetzsch, C.: Quantification of the unknown HONO daytime source and its relation to $\mathrm{NO}_{2}$, Atmos. Chem. Phys., 11, 10433-10447, doi:10.5194/acp-11-10433-2011, 2011 b.

Sosedova, Y., Rouviere, A., Bartels-Rausch, T., and Ammann, M.: UVA/Vis-induced nitrous acid formation on polyphenolic films exposed to gaseous $\mathrm{NO}_{2}$, Photochem. Photobiol. Sci., 10, 16801690, doi:10.1039/C1PP05113J, 2011.

Stemmler, K., Ammann, M., Donders, C., Kleffmann, J., and George, C.: Photosensitized reduction of nitrogen dioxide on humic acid as a source of nitrous acid, Nature, 440, 195-198, doi:10.1038/nature04603, 2006.

Stemmler, K., Ndour, M., Elshorbany, Y., Kleffmann, J., D’Anna, B., George, C., Bohn, B., and Ammann, M.: Light induced conversion of nitrogen dioxide into nitrous acid on submi- cron humic acid aerosol, Atmos. Chem. Phys., 7, 4237-4248, doi:10.5194/acp-7-4237-2007, 2007.

Stutz, J. and Platt, U.: Numerical analysis and estimation of the statistical error of differential optical absorption spectroscopy measurements with least-squares methods, Appl. Optics, 35, 60416053, 1996.

Stutz, J. and Platt, U.: Improving long-path differential optical absorption spectroscopy with a quartzfiber mode mixer, Appl. Optics, 36, 1105-1115, 1997.

Stutz, J., Kim, E., Platt, U., Bruno, P., Perrino, C., and Febo, A.: UV-visible absorption cross sections of nitrous acid, J. Geophys. Res., 105, 14585-14592, 2000.

Stutz, J., Alicke, B., Ackermann, R., Geyer, A., Wang, S., White, A., Williams, E., Spicer, C., and Fast, J.: Relative humidity dependence of HONO chemistry in urban areas, J. Geophys. Res., 109, D03307, doi:10.1029/2003JD004135, 2004.

Stutz, J., Oh, H.-J., Whitlow, S., Anderson, C., Dibb, J., Flynn, J., Rappenglück, B., and Lefer, B.: Simultaneous DOAS and mistchamber IC measurements of HONO in Houston, TX, Atmos. Environ., 44, 4090-4098, doi:10.1016/j.atmosenv.2009.02.003, 2010.

Su, H., Cheng, Y., Shao, M., Gao, D., Yu, Z., Zeng, L., Slanina, J., Zhang, Y., and Wiedensohler, A.: Nitrous acid (HONO) and its daytime sources at a rural site during the 2004 PRIDE-PRD experiment in China, J. Geophys. Res.-Atmos., 113, D14312, doi:10.1029/2007JD009060, 2008.

Su, H., Cheng, Y., Oswald, R., Behrendt, T., Trebs, I., Meixner, F., Andreae, M., Cheng, P., Zhang, Y., and Pöschl, U.: Soil nitrite as a source of atmospheric HONO and $\mathrm{OH}$ radicals, Science, 333, 1616-1618, doi:10.1126/science.1207687, 2011.

Vandaele, A., Hermans, C., Fally, S., Carleer, M., Colin, R., Merienne, M., Jenouvrier, A., and Coquart, B.: Highresolution Fourier transform measurement of the $\mathrm{NO}_{2}$ visible and near-infrared absorption cross sections: Temperature and pressure effects, J. Geophys. Res.-Atmos., 107, 4348, doi:10.1029/2001JD000971, 2002.

Villena, G., Kleffmann, J., Kurtenbach, R., Wiesen, P., Lissi, E., Rubio, M., Croxatto, G., and Rappenglück, B.: Vertical gradients of $\mathrm{HONO}, \mathrm{NO}_{x}$ and $\mathrm{O}_{3}$ in Santiago de Chile, Atmos. Environ., 45, 3867-3873, doi:10.1016/j.atmosenv.2011.01.073, 2011.

Wong, K., Oh, H.-J., Lefer, B., Rappenglück, B., and Stutz, J.: Vertical profiles of nitrous acid in the nocturnal urban atmosphere of Houston, TX, Atmos. Chem. Phys., 11, 3595-3609, doi:10.5194/acp-11-3595-2011, 2011.

Zhang, N., Zhou, X., Shepson, P., Gao, H., Alaghmand, M., and Stirm, B.: Aircraft measurement of HONO vertical profiles over a forested region, Geophys. Res. Lett., 36, L15820, doi:10.1029/2009GL038999, 2009.

Zhou, X., Beine, H., Honrath, R., Fuentes, J., Simpson, W., Shepson, P., and Bottenheim, J.: Snowpack photochemical production of HONO: a major source of $\mathrm{OH}$ in the Arctic boundary layer in springtime, Geophys. Res. Lett., 28, 4087-4090, doi:10.1029/2001GL013531, 2001.

Zhou, X., He, Y., Huang, G., Thornberry, T., Carroll, M., and Bertman, S.: Photochemical production of nitrous acid on glass sample manifold surface, Geophys. Res. Lett., 29, 1681, doi:10.1029/2002GL015080, 2002.

Zhou, X., Gao, H., He, Y., Huang, G., Bertman, S., Civerolo, K., and Schwab, J.: Nitric acid photolysis on surfaces in low- $\mathrm{NO}_{\mathrm{x}}$ 
environments: Significant atmospheric implications, Geophys. Res. Lett., 30, 2217, doi:10.1029/2003GL018620, 2003.

Zhou, X., Huang, G., Civerolo, K., Roychowdhury, U., and Demerjian, K.: Summertime observations of $\mathrm{HONO}, \mathrm{HCHO}$, and $\mathrm{O}_{3}$ at the summit of Whiteface Mountain, New York, J. Geophys. Res.-Atmos., 112, D08311, doi:10.1029/2006JD007256, 2007.

Zhou, X., Zhang, N., TerAvest, M., Tang, D., Hou, J., Bertman, S., Alaghmand, M., Shepson, P., Carroll, M., Griffith, S., Dusanter, S., and Stevens, P.: Nitric acid photolysis on forest canopy surface as a source for tropospheric nitrous acid, Nat. Geosci., 4, 440-443, doi:10.1038/NGEO1164, 2011.
Ziemba, L., Dibb, J., Griffin, R., Anderson, C., Whitlow, S., Lefer, B., Rappenglück, B., and Flynn, J.: Heterogeneous conversion of nitric acid to nitrous acid on the surface of primary organic aerosol in an urban atmosphere, Atmos. Environ., 44, 40814089, doi:10.1016/j.atmosenv.2008.12.024, 2010. 